\title{
Interplay among SNAIL Transcription Factor, MicroRNAs, Long Non-Coding RNAs, and Circular RNAs in the Regulation of Tumor Growth and Metastasis
}

\author{
Klaudia Skrzypek *(D) and Marcin Majka *(D) \\ Jagiellonian University Medical College, Faculty of Medicine, Institute of Pediatrics, Department of \\ Transplantation, Wielicka 265, 30-663 Cracow, Poland \\ * Correspondence: klaudia.skrzypek@uj.edu.pl (K.S.); mmajka@cm-uj.krakow.pl (M.M); \\ Tel.: +48-12-659-15-93 (K.S. \& M.M.)
}

Received: 20 November 2019; Accepted: 9 January 2020; Published: 14 January 2020

\begin{abstract}
SNAIL (SNAI1) is a zinc finger transcription factor that binds to E-box sequences and regulates the expression of genes. It usually acts as a gene repressor, but it may also activate the expression of genes. SNAIL plays a key role in the regulation of epithelial to mesenchymal transition, which is the main mechanism responsible for the progression and metastasis of epithelial tumors. Nevertheless, it also regulates different processes that are responsible for tumor growth, such as the activity of cancer stem cells, the control of cell metabolism, and the regulation of differentiation. Different proteins and microRNAs may regulate the SNAIL level, and SNAIL may be an important regulator of microRNA expression as well. The interplay among SNAIL, microRNAs, long non-coding RNAs, and circular RNAs is a key event in the regulation of tumor growth and metastasis. This review for the first time discusses different types of regulation between SNAIL and non-coding RNAs with a focus on feedback loops and the role of competitive RNA. Understanding these mechanisms may help develop novel therapeutic strategies against cancer based on microRNAs.
\end{abstract}

Keywords: tumor; metastasis; microRNA; SNAIL (SNAI1) transcription factor; epithelial to mesenchymal transition (EMT); long non-coding RNAs (lncRNAs); circular RNAs

\section{Introduction: Background of SNAIL Transcription Factor}

SNAIL is a member of the group of conservative zinc finger transcription factors. It was first described in Drosophila melanogaster as an essential factor for the mesoderm formation [1]. Subsequently, its homologues have been described in many species, including humans. The SNAIL family consists of three members: SNAIL (SNAI1), SLUG (SNAI2), and SMUG (SNAI3) [2]. The SNAIL protein contains C-terminal zinc finger domains that are responsible for DNA binding, the N-terminal SNAG domain responsible for interaction with several co-repressors or epigenetic remodeling complexes, the serine-rich domain (SRD) regulating ubiquitination and proteasome degradation, and the nuclear export sequence (NES) that controls the protein stability and subcellular localization [3].

\subsection{SNAIL Expression and Regulation}

SNAIL expression may be regulated by many signaling pathways. At the transcriptional level, SNAIL is regulated by multiple growth factors and signaling molecules that are responsible for the subsequent regulation of the SNAIL promoter, including transforming growth factor $\beta$ (TGF- $\beta$ ), fibroblast growth factor 2 (FGF2), epidermal growth factor (EGF), Harvey rat sarcoma 
viral oncogene homolog (H-ras), Akt kinase-transforming protein (v-Akt), and nuclear factor kappa-light-chain-enhancer of activated B cells/protein 65 (NF-kB/p65) [4,5]. Post-translational modifications, such as phosphorylation, ubiquitination, and lysine oxidation also regulate SNAIL level. Glycogen synthase kinase 3 beta (GSK-3 $\beta$ ) phosphorylates SNAIL at two consensus motifs. Phosphorylation of the first motif regulates ubiquitination and degradation in the proteasome, whereas phosphorylation of the second motif regulates its subcellular localization [6]. Lysyl oxidase-like 2 (LOXL2) enzyme interaction regulates SNAIL stability [7] by interfering with FBXL14 binding SNAIL. FBXL14 (F-box and leucine-rich repeat protein 14) is a ubiquitin ligase that targets both phosphorylated and unphosphorylated SNAIL for proteasome degradation [8]. SNAIL can also be stabilized by hyperglycemia-regulated O-linked $\beta$-N-acetylglucosamine (O-GlcNAc) modification of serine [9]. Moreover, SNAIL can be stabilized by NF-KB, which induces COP9 signalosome 2 (CSN2), which, in turn, blocks the ubiquitination and degradation of SNAIL [10]. The phosphorylation of SNAIL may result in an increased retention of the protein in the nucleus. That mechanism of action was described for p21-activated kinase (PAK1), which phosphorylates SNAIL at Ser 246 [11].

\subsection{Different Pathways Regulated by SNAIL}

SNAIL plays an important role in the regulation of epithelial to mesenchymal transition in embryo development: gastrulation and mesoderm formation [2]. However, molecular mechanisms of certain pathological stages resemble those observed in physiological process. One of them is epithelial to mesenchymal transition (EMT) during cancer progression. It is the main mechanism responsible for the invasiveness and metastasis of neoplasm at the advanced stages [12]. SNAIL exerts its effects by decreasing the expression of E-cadherin by binding to its promoter [13]. Nevertheless, SNAIL is a transcriptional repressor, which binds to regulatory regions and promoters containing sequences called E-boxes, and thereby it regulates the expression of many different genes and in this way, it may also regulate EMT. The SNAIL family contains a highly conserved region of four to six zinc fingers that allows them to interact with those E-box sequences (CANNTG). Since these sequences are also recognized by transcription factors from the basic helix-loop-helix (bHLH) family, the role of SNAIL factors is mainly focused on transcription repression by excluding these proteins from their binding sites [2]. SNAIL is capable of interacting with HDAC1/2 histone deacetylase, which causes a local modification of the chromatin structure and blocks the expression of E-cadherin, the loss of which is a marker of epithelial-mesenchymal transition (EMT) [13]. As E-box sequences are present in the promoters of many different genes, in the literature, SNAIL is described as a regulator of many genes important in tumorigenesis, such as cyclin D2, proliferating cell nuclear antigen (PCNA), prostaglandin dehydrogenase, ATPase1, etc. [12]. SNAIL turned out to be also a direct regulator of not only EMT in tumor progression, but also of myogenic differentiation. The binding of SNAIL to E-box sequences in the myogenic factor 5 (MYF5) promoter and recruiting histone deacetylases (HDACs) was described in the regulation of rhabdomyosarcoma development [14]. Another example of the non-canonical actions of SNAIL is the regulation of myoblast determination protein 1 (MyoD) function in myogenic differentiation by the competitive binding of SNAIL to its regulatory sequences [15]. Nevertheless, SNAIL is not only described as a transcriptional repressor, but also as the transcriptional activator. For example, SNAIL induces the expression of mesenchymal genes, such as vimentin, fibronectin, matrix metalloproteinases MMP-2, and MMP-9. In that way, it further facilitates the increased motility of cells [16].

What is more, the recent data demonstrated the mechanism of self-regulation by members of the SNAIL family: the SNAIL-binding site is present in the SNAIL promoter (negative feedback) [17], and avian Slug can self-activate during the neural crest development [18]. Moreover, in ovarian cancer cells, SNAIL binds to two E-box sequences in SLUG promoter and represses SLUG, which is predominantly mediated through the recruitment of the HDACs [19].

SNAIL plays a role in many physiological and pathological processes, such as chronic inflammation, fibrosis, EMT induction, the regulation of cancer stem cells, the control of cell metabolism, the 
suppression of estrogen receptor signaling, and in particular the development and metastasis of tumors [3]. Currently, many research papers focus not only on interaction between SNAIL and different genes, but also on the interplay between SNAIL and non-coding RNAs, such as microRNAs, long non-coding RNAs, and circular RNAs [20]. In this review, we discuss recent advances in those fields. We present bidirectional crosstalk between SNAIL and non-coding RNAs with implications of these new findings on tumor progression, which may help develop novel therapeutic strategies in future.

\section{Non-Coding RNAs as Regulators of Tumor Progression}

Non-coding RNAs (ncRNAs) are a class of RNA transcripts that do not encode proteins, but they may play a role in the regulation of gene expression at transcriptional, translational, and post-translational levels. Among regulatory ncRNAs, long non-coding RNAs, small RNAs, and circular RNAs may be distinguished [21] (Figure 1), and they are described in this review.

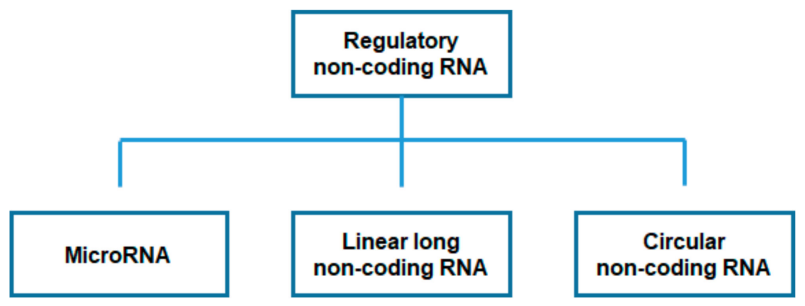

Figure 1. Scheme presenting the selected regulatory non-coding RNAs.

Long non-coding RNAs (lncRNAs) are RNA transcripts with a length greater than 200 nucleotides. They can regulate gene expressions and functions. Therefore, they are involved in the pathogenesis of many diseases, including cancer. Nevertheless, there are papers revealing that some lncRNAs contain cryptic open reading frames (ORFs), which may blur the distinction between protein-coding and non-coding transcripts [22]. IncRNAs can originate from their own promoters or from the promoters shared with other coding or non-coding genes, or from enhancer sequences. IncRNAs are usually transcribed by RNA polymerase II or RNA polymerase III. They are often 5'-capped, spliced, and polyadenylated, but they are usually shorter than mRNAs [23,24]. IncRNAs may be co-regulated with mRNAs in expression networks. IncRNAs may also be generated from the divergent transcription from shared protein-coding gene promoters. Divergent transcription generates the sense (mRNA) and anti-sense RNAs [24,25]. IncRNA promoters are usually evolutionarily conserved and tightly regulated, and they are prone to epigenetic modification [23]. lncRNAs may also be processed in different ways than mRNAs, such as RNase P-processed 3' maturation, which was shown for MALAT1 (metastasis associated lung adenocarcinoma transcript 1) [24]. DICER1 endonuclease is an important factor in both the biogenesis of miRNAs that may also act as a downstream activator of many lncRNAs [26]. What is also interesting is that few miRNAs are derived from lncRNA exons [27]. IncRNAs participate in and modulate the various cellular processes, such as cellular transcription, the modulation of chromatin structure, DNA methylation, or histone modification. They may act as a sponge for microRNAs and as a competing endogenous RNAs (ceRNAs) [28].

Circular RNA (circRNA) is a type of single-stranded RNA that forms a covalently closed continuous loop that is insensitive to ribonucleases. circRNAs are formed by exon skipping or back-splicing events. circRNAs are produced by nonsequential exon-exon back-splicing, which results in a chemically circularized transcript in which $3^{\prime}$ sequences are spliced upstream of $5^{\prime}$ sequences, and they have special $5^{\prime}$ and $3^{\prime}$-end processing [24]. Alternative splicing factor quaking is a regulator of that circularization during EMT [29]. There is also a class of circular intronic lncRNA (ciRNAs) that are generated from stabilized introns after canonical splicing. They display regulatory functions, mostly at their transcription sites [30]. There are also exon-intron circRNAs (elciRNAs) that represent a class of circular RNAs that retain unspliced introns. Their role involves induction of the transcription of their parental genes via interaction with polymerase II and U1 snRNP (small nuclear ribonucleoprotein) [31]. 
circRNAs are closely associated with tumor metastasis and patient prognosis, because they are differentially expressed in different tumor types. They may act as a microRNA sponge and interact with proteins [32]. Nevertheless, recent research papers provide initial evidence for certain endogenous circRNAs coding for proteins [33].

MicroRNAs (miRNAs) are a class of approximately 22 nucleotides small non-coding RNAs. They can regulate the expression of genes and translation of proteins by interfering with ribosomal machinery. They commonly target the $3^{\prime}$ untranslated regions ( $3^{\prime}$ UTRs) of mRNAs and in that way decrease their stability and suppress translation. Nevertheless, they can also activate other genes [34,35]. Genes highly and constitutively expressed usually display shorter 3' UTR sites and in consequence only a few binding sites for miRNAs. Accordingly, genes potently regulated during development display multiple binding sites for miRNAs [36].

miRNAs can be expressed at high levels (even up to tens of thousands of copies per cell), and they act as important regulatory factors, controlling hundreds of mRNA targets [37]. Animal miRNAs target the 3' UTRs of different mRNAs by seed sequence complementarity. They usually repress translation more often than they cleave mRNA [35,38,39].

miRNAs are located in introns of coding genes, in exons, or in non-protein coding DNA regions. miRNAs have their own promoters, and they are independently expressed. Some of them are also organized in clusters sharing the same transcriptional regulation. miRNAs can arise from spliced introns, which are often termed miRtrons, or their own promoter, driving the expression of a single miRNA or polycistron yielding multiple pre-miRNA stem loops [40]. Nevertheless, miRNA transcription may also be dependent on the host gene. Intronic miRNAs can be expressed together with their host gene mRNA, and they can be derived from a common transcript [41]. Many non-canonical miRNA biogenesis pathways have also been characterized [42].

miRNAs are transcribed by polymerase II, sometimes as polycistronic transcripts. miRNA stem loops are excised from the primary transcripts (pri-miRNA) in the nucleus by endoribonuclease Drosha, acting together with DGCR8. Then, the excised 70-100 nt hairpin called pre-miRNA is actively transported from the nucleus to cytoplasm in a GTP (guanosine-5' ${ }^{\prime}$-triphosphate)-dependent manner. The export is mediated by exportin 5 and Ran GTPase. Subsequently in the cytoplasm, the pre-miRNA is cleaved by Dicer endonuclease, giving the mature miRNA—a base-paired double-stranded processing intermediate with a $2 \mathrm{nt} 3^{\prime}$ overhang. Two strands are generated. Then, one strand of the duplex is incorporated into RNA-induced silencing complexes (RISC) with the Argonaute protein, which is capable of endonucleolytic cleavage [42,43]. The translational repression is characterized by low miRNA-target complementarity, whereas mRNA degradation requires a high miRNA-target complementarity [44].

Alterations of miRNAs expression in various cancers have been described in the literature. Firstly, in 2002, they were shown in the most common form of adult leukemia, B cell chronic lymphocytic leukemia [45] and then in 2003 in colorectal cancers [46]. It soon turned out that miRNAs can be differentially expressed in different tumor types as either benign or malignant, and they can also act as biomarkers [47].

Global miRNA downregulation is a common trait of many tumors [48,49]. Accordingly, the diminished expression of miRNA processing factors is also associated with the poor prognosis of different cancer types [50].

What is more, some miRNAs' loci often display genomic instability in cancer, and they are located in cancer-associated genomic regions or in fragile sites. It was also demonstrated that several miRNAs located in deleted regions are expressed at low levels in cancer [51].

Cancer cells can also escape from miRNA regulation by the production of mRNAs with shortened 3'UTR and fewer miRNA target sites. This global switch of the use of miRNA-mediated gene regulation is associated with an increased proliferation or cellular transformation [50]. These findings are consistent with the widespread decrease of miRNAs in cancer $[48,49]$. 
Some miRNAs can behave as oncogenes favoring tumorigenesis. They are called oncomirs. They can reduce the levels of proteins blocking proliferation and migration and activating apoptosis. Many miRNAs were identified as oncomirs in different types of tumors. For example, members encoded by the miR-17-92 cluster were previously associated with carcinogenesis and usually display increased expression in tumors, including lung cancer [52,53].

On the other hand, tumor-suppressive miRNAs can inhibit cancer development. Their inactivation in tumors is followed by the accumulation of proteins stimulating proliferation and migration and decreasing apoptosis. For example, miR-181a and miR-181b were described to act as tumor suppressors in glioma [54] and miR-181a in non-small cell lung carcinoma [55]. Interestingly, plenty of miRNAs may behave oppositely in different types of tumors. For example, miR-34c can exert tumor-suppressive functions in prostate cancer [56], but in lung adenocarcinoma with different oncogenic mutations, it was reported to be upregulated [57].

miRNAs can affect tumor progression also by modulation of the development of new blood vessels. miRNAs promoting angiogenesis are called angiomirs, and they can target genes that are important in angiogenic processes [58].

Currently, miRNAs' role in the regulation of epithelial to mesenchymal transition has been widely described in the literature [59]. Since SNAIL is one of the crucial factors regulating EMT, the interplay between SNAIL and miRNAs may be a key factor in the regulation of tumor progression.

\section{MicroRNAs Regulating SNAIL}

\subsection{MicroRNAs Directly Targeting SNAIL}

MiRNAs can act as regulators of SNAIL expression by binding to the $3^{\prime} \mathrm{UTR}$ of SNAIL. Bioinformatical analysis using TargetScanHuman 7.1 [60] revealed several binding sites for different miRNAs in this region in human cells (Figure 2), and most of them have been already verified in the literature. For example, the SNAIL 3'UTR was shown to function as a sponge for multiple migration and invasion-related miRNA candidates including miR-153, miR-199a-5p, miR-203, miR-204, miR-22, miR-34a and miR-34c [61].

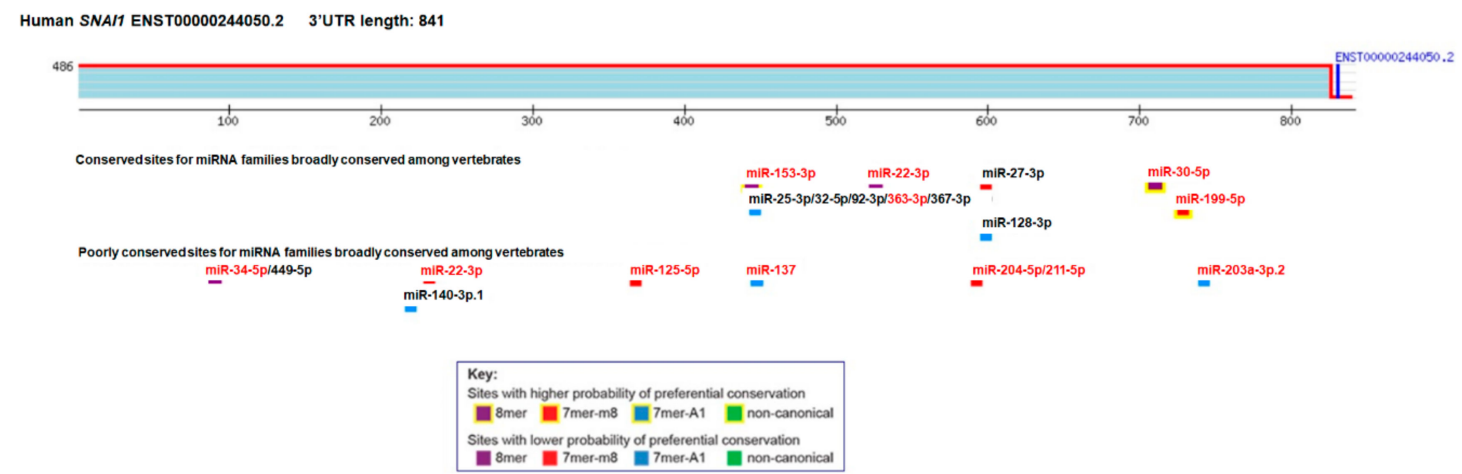

Figure 2. MicroRNAs targeting the $3^{\prime}$ untranslated (3'UTR) region of SNAIL from bioinformatical analysis using TargetScanHuman 7.1 (access: 22 October 2019). Experimental evidence for direct binding to SNAIL 3'UTR was shown in the literature for miR-153, miR-22, miR-30, miR-363, miR-199, miR-34, miR-22, miR-137, miR-203, miR-125, miR-211, and miR-203 (marked in red), which is described in the text below.

Several miRNAs were experimentally validated to target SNAIL 3'UTR, and subsequently, their role was described in different tumor types. One of the crucial regulators of SNAIL expression widely described in the literature is the miR-30 family. Members of this family target the 3'UTR of SNAIL mRNA in non-small cell lung carcinoma [62], breast cancer [63], pancreatic cancer stem cells [64], melanoma [65], esophageal squamous cell carcinoma [66], rhabdomyosarcoma [14], or in hepatocytes $[67,68]$. This inhibition usually regulates EMT in epithelial tumor types, but in mesenchymal 
tumors, such as rhabdomyosarcoma, it may be responsible for non-canonical SNAIL action [14]; it might also be important in different processes, such as atherosclerosis [69]. Moreover, miR-30a was also shown to regulate not only SNAIL but also SLUG in breast cancer to suppress EMT and metastasis [70].

SNAIL-dependent EMT in cancer has also been demonstrated to be regulated by p53 and miR-34 axis. In the absence of wild-type p53 function, SNAIL-dependent EMT is activated in colon, breast, lung carcinoma cells [71], and ovarian cancer [72] as a consequence of a decrease in miR-34 levels. A conserved miR-34a/b/c seed-matching sequence was detected in the SNAIL 3'-UTR. Moreover, there is a double-negative feedback loop in the regulation of EMT formed by miR-34 and SNAIL [73]. Luciferase reporter assays revealed that in pancreatic cancer, miR-34a targets both SNAIL and NOTCH1 to inhibit pancreatic cancer progression through the regulation of EMT and NOTCH signaling pathways [74].

Another example of miRNA that is described as a direct regulator of SNAIL expression in plenty tumor types is miR-153. The downregulation of SNAIL by miR-153 suppresses human laryngeal squamous cell carcinoma migration and invasion [75], melanoma cells proliferation and invasion [76], esophageal squamous cell carcinoma progression [77], and gastric cancer metastasis [78]; regulates EMT in hepatocellular carcinoma [79]; and diminishes pancreatic ductal adenocarcinoma migration and invasion with miR-153 serving as a prognostic marker [80].

MiR-22 was demonstrated to target SNAIL and thereby inhibit tumor cell EMT and invasion in lung [81] and bladder cancer [82], in melanoma [83] and gastric cancer [84]. In bladder cancer, it inhibits both SNAIL and MAPK1 (mitogen-activated protein kinase 1) /SLUG/vimentin feedback loop [82], whereas in melanoma and gastric cancer it acts as a tumor suppressor by targeting both SNAIL and MMP14 [83,84].

SNAIL was found to be a target of multiple miRNAs in different tumor types. SNAIL was targeted in breast cancer by miR-125b [85], miR-203 [86], miR-410-3p [87], and miR-182 [88]; in gastric cancer by miR-491-5p [89] and miR-204 [90]; in lung cancer by miR-199a [91] and miR-940 [92]; in papillary thyroid carcinoma by miR-199a [93]; in ovarian cancer by miR-137 [72] and miR-363 [94]; in hepatocellular carcinoma by miR-122 [95] and miR-502-5p [96]; in prostate cancer by miR-486-5p [97]; and in renal cancer by miR-211-5p [98]. What is more, besides tumorigenesis, SNAIL is also regulated in different processes by miRNAs. For example, miR-133 promotes cardiac reprogramming by the direct repression of SNAIL and silencing fibroblast signatures [99], whereas miR-130b directly targets SNAIL in the regulation of diabetic nephropathy [100]. The results described above are summarized in Table 1.

Table 1. MicroRNAs regulating SNAIL.

\begin{tabular}{ccc}
\hline MicroRNA & Cancer/Cell Type & References \\
\hline \multirow{3}{*}{ miR-22 } & lung cancer & {$[81]$} \\
\cline { 2 - 3 } & bladder cancer & {$[82]$} \\
\cline { 2 - 3 } & melanoma & {$[83]$} \\
\hline \multirow{2}{*}{ miR-30 family } & gastric cancer & {$[84]$} \\
\cline { 2 - 3 } & preast cancer & {$[62]$} \\
\cline { 2 - 3 } & pancreatic cancer & {$[63]$} \\
\cline { 2 - 3 } & melanoma & {$[64]$} \\
\hline & esophageal squamous cell carcinoma & {$[65]$} \\
\hline & rhabdomyosarcoma & {$[66]$} \\
\hline
\end{tabular}


Table 1. Cont.

\begin{tabular}{|c|c|c|}
\hline MicroRNA & Cancer/Cell Type & References \\
\hline \multirow{5}{*}{ miR-34 } & colon carcinoma & [71] \\
\hline & breast carcinoma & [71] \\
\hline & lung carcinoma & [71] \\
\hline & ovarian cancer & [72] \\
\hline & pancreatic cancer & {$[74]$} \\
\hline $\operatorname{miR}-122$ & hepatocellular carcinoma & [95] \\
\hline $\operatorname{miR}-125 b$ & breast cancer & [85] \\
\hline miR-130b & diabetic nephropathy & [100] \\
\hline miR-133 & fibroblasts & [99] \\
\hline miR-137 & ovarian cancer & [72] \\
\hline \multirow{6}{*}{$\operatorname{miR}-153$} & laryngeal squamous cell carcinoma & [75] \\
\hline & melanoma & [76] \\
\hline & esophageal squamous cell carcinoma & [77] \\
\hline & gastric cancer & [78] \\
\hline & hepatocellular carcinoma & [79] \\
\hline & pancreatic ductal adenocarcinoma & [80] \\
\hline $\operatorname{miR}-182$ & breast cancer & [88] \\
\hline \multirow{2}{*}{ miR-199a } & lung cancer & [91] \\
\hline & papillary thyroid carcinoma & [93] \\
\hline miR-203 & breast cancer & [86] \\
\hline miR-204 & gastric cancer & [90] \\
\hline miR-211-5p & renal cancer & [98] \\
\hline miR-363 & ovarian cancer & [94] \\
\hline $\operatorname{miR}-410-3 p$ & breast cancer & [87] \\
\hline miR-486-5p & prostate cancer & [97] \\
\hline $\operatorname{miR}-491-5 p$ & gastric cancer & [89] \\
\hline $\operatorname{miR}-502-5 p$ & hepatocellular carcinoma & [96] \\
\hline miR-940 & lung cancer & [92] \\
\hline
\end{tabular}

\subsection{Other Examples of SNAIL Regulation by MicroRNAs}

The indirect regulation of SNAIL involves several different mechanisms. One of the examples is inhibition of the GSK-3 $\beta$ (glycogen synthase kinase 3 beta) pathway. miR-148a binds to the $3^{\prime}$-UTR region of $M E T$, which results in the attenuation of its downstream signaling, inhibition of AKT-Ser473 and GSK-3 $\beta$ phosphorylation, and in consequence reduced accumulation of SNAIL in the nucleus, the inhibition of EMT, and the metastasis of hepatoma cells [101]. In lung cancer cells, miR-126 affects the PI3K/AKT/SNAIL (phosphatidylinositol 3-kinase/protein kinase B/SNAIL) signaling pathway to regulate EMT [102]. A similar mechanism was described for miR-215 in papillary thyroid cancer [103]. In thyroid carcinoma, miR-101 targets the CXCL12 (C-X-C motif chemokine ligand 12, stromal cell-derived factor 1)-mediated AKT and SNAIL signaling pathways to inhibit invasion and the EMT-associated signaling pathways [104]. On the other hand, in hepatocellular carcinoma, miR-1306-3p targets FBXL5 to suppress SNAIL degradation and promote metastasis [105]. The SNAIL level can also be stabilized by miRNAs. miR-181b-3p promotes EMT in breast cancer cells 
through SNAIL stabilization by directly targeting the YWHAG protein [106]. In breast cancer cells, miR-5003-3p promotes EMT also through SNAIL stabilization via MDM2 and the direct targeting of E-cadherin [107]. In melanoma growth and metastasis, miR-9 is described as a downregulator of NF-kB1-SNAIL pathway [108]. The results described above are summarized in Table 2.

Table 2. Signaling pathways involving microRNAs that regulate SNAIL.

\begin{tabular}{|c|c|c|c|c|}
\hline MicroRNA & $\begin{array}{l}\text { Regulated Pathway } \\
\text { and Genes }\end{array}$ & $\begin{array}{c}\text { Mechanism of } \\
\text { SNAIL Regulation }\end{array}$ & Cancer/Cell Type & References \\
\hline $\operatorname{miR}-9$ & NF-kB1 & SNAIL expression & melanoma & [108] \\
\hline miR-101 & CXCL12-mediated AKT & SNAIL localization & thyroid carcinoma & [104] \\
\hline miR-126 & PI3K-AKT & SNAIL localization & lung cancer & [102] \\
\hline miR-148a & MET/AKT/GSK-3 $\beta$ & $\begin{array}{l}\text { SNAIL localization } \\
\text { and degradation }\end{array}$ & hepatoma cells & [101] \\
\hline miR-181b-3p & YWHAG protein & $\begin{array}{c}\text { SNAIL } \\
\text { stabilization }\end{array}$ & breast cancer & [106] \\
\hline $\operatorname{miR}-215$ & PI3K-AKT & SNAIL localization & $\begin{array}{l}\text { papillary thyroid } \\
\text { cancer }\end{array}$ & [103] \\
\hline miR-1306-3p & FBXL5 & $\begin{array}{c}\text { Suppression of } \\
\text { SNAIL degradation }\end{array}$ & $\begin{array}{l}\text { hepatocellular } \\
\text { carcinoma }\end{array}$ & [105] \\
\hline miR-5003-3p & MDM2, E-cadherin & $\begin{array}{c}\text { SNAIL } \\
\text { stabilization }\end{array}$ & breast cancer & [107] \\
\hline
\end{tabular}

Sometimes, the research data demonstrate the regulation of SNAIL expression by miRNAs, but it is not described if the regulation is direct or indirect. There are also several other examples of miRNAs regulating the SNAIL level. In ovarian cancer, miR-16 is associated with the downregulation of mesenchymal markers, such as SNAIL, SLUG, and vimentin [109]. In Wilms' tumor cells, miR-483-3p regulates EMT by the modulation of E-cadherin, N-cadherin, SNAIL, and vimentin expression [110]. In osteosarcoma, the downregulation of miR-145 promotes EMT by regulation of the SNAIL level [111]. In rhabdomyosarcoma, miR-410-3p inhibits tumor growth and progression by inhibition of the expression of SNAIL, SLUG, N-cadherin, and Bcl-2 [112]. However, miR-410-3p was shown previously in different tumor types to directly target SNAIL [87].

The miRNAs-SNAIL axis may regulate not only EMT, but also the activity of cancer stem cells. miR-210 induced by a hypoxic microenvironment favored breast cancer stem cells' metastasis, proliferation, and self-renewal by targeting E-cadherin and the upregulation of SNAIL [113]. Another example is miR-146a, which directs the symmetric division of SNAIL-dominant colorectal cancer stem cells [114].

\subsection{Regulation of SLUG Expression by MicroRNAs}

MiRNAs can regulate not only SNAIL, but also SLUG, which is another important factor from the SNAIL family. Some miRNAs can regulate both factors. Among them are miR-30a [70], miR-122 [95], miR-182 [115], and miR-203 [115] and miR-204 [116]. SLUG is targeted in in oral squamous cell carcinoma by miR-204 [116]; glioblastoma by miR-203 [117]; in lung cancer by miR-1 [118]; in breast cancer by miR-124 [119,120], miR-30a [70], miR-497 [121], miR-1271 [122], and miR-203 [123,124]; in gastric cancer by miR-33a [125]; in lung cancer by miR-218 [126]; in clear cell renal cell carcinoma by miR-1 [127]; in osteosarcoma by miR-124 [128]; and in gingival fibroblasts by miR-200b [129]. Similarly to SNAIL, miRNAs-SLUG action regulates EMT in cancer progression, as well as different processes, such as the modulation of cancer stem cells' activity. miR-204 binds to the 3'UTR regions of both SLUG and SOX4 to suppress osteosarcoma cancer stem cells [117], whereas the loss of miR-124 enhances the stem-like traits of glioma cells [130]. The miRNAs-SLUG axis is also important in 
other biological processes, such as for example in traumatic heterotopic ossification. miR-630 inhibits endothelial-mesenchymal transition by targeting SLUG [131]. The regulation of SLUG expression by miRNAs is summarized in Table 3.

Table 3. MicroRNAs regulating SLUG.

\begin{tabular}{ccc}
\hline MicroRNA & Cancer/Cell Type & References \\
\hline miR-1 & lung cancer & {$[118]$} \\
\hline miR-30a & breast cancer & {$[70]$} \\
\hline miR-33a & gastric cancer & {$[125]$} \\
\hline \multirow{2}{*}{ miR-124 } & breast cancer & {$[119,120]$} \\
\cline { 2 - 3 } & osteosarcoma & {$[128]$} \\
\cline { 2 - 3 } & glioma & {$[130]$} \\
\hline miR-200b & gingival fibroblasts & {$[129]$} \\
\hline \multirow{2}{*}{ miR-203 } & glioblastoma & {$[117]$} \\
\hline miR-204 & breast cancer & {$[123,124]$} \\
\hline miR-218 & oral squamous cell carcinoma & {$[116]$} \\
\hline miR-497 & lung cancer & {$[126]$} \\
\hline miR-630 & breast cancer & {$[121]$} \\
\hline miR-1271 & dermal microvascular endothelial cells & {$[131]$} \\
\hline & breast cancer & {$[122]$} \\
\hline
\end{tabular}

\section{LncRNA, CircRNAs, and their Relationship to SNAIL and Targeting MicroRNAs}

Besides miRNAs, an interesting mechanism of action in the regulation of SNAIL or SLUG expression is also described for long non-coding RNAs (lncRNA). The may act as sponges for miRNAs targeting SNAIL. LncRNA MALAT1 (metastasis associated lung adenocarcinoma transcript 1) acts as a competing endogenous RNA (ceRNA) by sponging miR-22 to promote melanoma growth and metastasis [83]. MALAT1 turned out to be a regulator of not only miR-22, but also miR-1-3p expression. In that way, it inhibits migration, invasion, and EMT, which leads to the increased expression of E-cadherin and decreased expression of vimentin, SLUG, and SNAIL [132]. Another interesting feature of MALAT1 is the modulation of cancer stem cells' (CSC) activity by regulation of the miR-1/SLUG axis in nasopharyngeal carcinoma [133]. In gastric cancer, miR-22 is also regulated by lncRNA H19 with effects on metastasis via the miR-22-3p/SNAIL axis [134]. Another example in gastric cancer is lncRNA SNHG7 (small nucleolar RNA host gene 7), which directly binds to miR-34a and suppresses the miR-34a-SNAIL-EMT axis, which regulates gastric cancer cell migration and invasion [135].

SLUG level can also be regulated by other lncRNAs. For example, lncRNA GAPLINC (gastric adenocarcinoma associated) promotes the invasion of colorectal cancer by binding to PSF/NONO (probable DNA replication complex GINS protein PSF/non-POU domain-containing octamer-binding protein) and partly by stimulating the expression of SLUG [136]. IncRNA CAR10 directly binds two miRNAs: miR-30 and miR-203 and hence regulates the expression of both SNAIL and SLUG. In that way, it induces EMT and promotes lung adenocarcinoma metastasis [137]. In that cancer type, another example is lncRNA HCP5 acting as a sponge for miR-203 [138]. miR-203 interacts also with lncRNA UCA1 in hepatocellular carcinoma, and in that way, SLUG expression is regulated in tumor progression [139]. In that cancer type, IncRNA-AB209371 binds to hsa-miR199a-5p and weakens the inhibitory effect of hsa-miR199a-5p on SNAIL expression to promote EMT [140]. In breast cancer, lncRNA TINCR (terminal differentiation-induced ncRNA) targets miR-125b, and in that way regulates SNAIL and EMT [85].

LncRNAs may regulate the SNAIL level not only by miRNAs, but also epigenetically. LncRNA SATB2-AS1 (the antisense transcript of SAT2B-special AT-rich sequence-binding protein 2) mediates the epigenetic regulation of SNAIL expression in colorectal cancer progression. SATB2-AS1 
recruits p300, whose acetylation of $\mathrm{H} 3 \mathrm{~K} 27$ and $\mathrm{H} 3 \mathrm{~K} 9$ at the SATB2 promoter and subsequently the elevated SATB2 recruits HDAC1 to the SNAIL promoter to repress its transcription [141].

The interaction of lncRNAs with SNAIL is also possible. IncRNA NEAT1 (nuclear enriched abundant transcript 1) epigenetically suppresses E-cadherin expression in osteosarcoma cells by association with the G9a-DNMT1 (DNA methyltransferase 1)—SNAIL complex [142].

lncRNAs may also regulate the level of transcription factor by increasing their stability. For example, lncRNA SNHG15 impedes SLUG ubiquitination and its proteasomal degradation by interaction with the zinc finger domain of SLUG [143].

Besides lncRNAs, circular RNAs (circRNAs) were also described as SNAIL regulators. In hepatocellular carcinoma, circ-ZNF652 could physically interact with miR-203 and miR-502-5p to increase the expression of SNAIL. circ-ZNF652 was identified as a novel driver of EMT [96]. Similarly, in melanoma, circRNA_0084043 promotes progression via the miR-153-3p/SNAIL axis [144]. In urothelial carcinoma, circRNA PRMT5 acts as a sponge for miR-30c, which affects the SNAIL/E-cadherin pathway and thereby induces EMT [145]. circRNAs may be also implicated in the regulation of SLUG level. For example, circRNA-000284 can positively regulate the SLUG level in cervical cancer by sponging miR-506, which directly binds to SLUG $3^{\prime}$ UTR [146].

The indirect regulation of SNAIL level by several mediators is also possible. Circular RNA hsa_circ_0008305 (circPTK2) inhibits TGF- $\beta$-induced EMT in non-small cell lung cancer by direct binding to miR-429/miR-200b-3p, which act as direct regulators of TIF1 $\gamma$ (transcriptional intermediary factor $1 \gamma$ ), resulting in diminished SNAIL expression [147]. CircPIP5K1A induces non-small cell lung cancer progression by the regulation of miR-600/HIF-1 $\alpha$ (hypoxia-inducible factor 1-alpha), which results in the upregulation of EMT-related factors, such as SNAIL [148]. Circ_0026344 promotes colorectal carcinoma invasion by targeting miR-183, which increases EMT and upregulates mesenchymal markers and SNAIL [149].

To summarize, SNAIL is regulated by signaling networks involving plenty of miRNAs, long non-coding RNAs, and circular RNAs (Table 4). lncRNAs and circRNAs usually act as sponges for miRNAs targeting SNAIL (Figure 3). This mechanism may be responsible for the regulation of tumor progression.

Table 4. Long non-coding RNAs regulating SNAIL and SLUG.

\begin{tabular}{|c|c|c|c|c|}
\hline LncRNA/CircRNA & Regulated MicroRNAs & Regulated Factors & Cancer & References \\
\hline \multirow{3}{*}{ IncRNA MALAT1 } & miR-22 & SNAIL & melanoma & [83] \\
\hline & miR-22 and miR-1-3p & E-cadherin, vimentin, SLUG and SNAIL & prostate cancer & [132] \\
\hline & miR-1 & SLUG & nasopharyngeal carcinoma & [133] \\
\hline lncRNA H19 & $\mathrm{miR}-22-3 p$ & SNAIL & gastric cancer & [134] \\
\hline lncRNA SNHG7 & miR-34a & SNAIL & gastric cancer & [135] \\
\hline lncRNA CAR10 & miR-30 and miR-203 & SNAIL and SLUG & lung adenocarcinoma & [137] \\
\hline lncRNA HCP5 & miR-203 & SNAIL & lung adenocarcinoma & [138] \\
\hline lncRNA UCA1 & miR-203 & SLUG & hepatocellular carcinoma & [139] \\
\hline lncRNA AB209371 & miR199a-5p & SNAIL & hepatocellular carcinoma & [140] \\
\hline lncRNA TINCR & $\mathrm{miR}-125 \mathrm{~b}$ & SNAIL & breast cancer & [85] \\
\hline lncRNA SATB2-AS1 & - & SNAIL (epigenetic regulation involving SATB2) & colorectal cancer & [141] \\
\hline lncRNA NEAT1 & - & $\begin{array}{l}\text { E-cadherin by association with } \\
\text { G9a-DNMT1-SNAIL complex }\end{array}$ & osteosarcoma cells & [142] \\
\hline lncRNA SNHG15 & - & $\begin{array}{l}\text { SNAIL (ubiquitination by interaction with zinc } \\
\text { finger domain) }\end{array}$ & colon cancer & [143] \\
\hline lncRNA GAPLINC & - & SLUG (by binding to PSF/NONO) & colorectal cancer & [136] \\
\hline circ-ZNF652 & miR-203 and miR-502-5p & SNAIL & hepatocellular carcinoma & [96] \\
\hline circRNA_0084043 & miR-153-3p & SNAIL & melanoma & [144] \\
\hline circRNA PRMT5 & $\mathrm{miR}-30 \mathrm{c}$ & SNAIL & urothelial carcinoma & [145] \\
\hline circRNA-000284 & miR-506 & SLUG & cervical cancer & [146] \\
\hline hsa_circ_0008305 (circPTK2) & $\begin{array}{l}\text { miR-429 and } \\
\text { miR-200b-3p }\end{array}$ & SNAIL (indirectly by TIF1 $\gamma$ ) & non-small cell lung cancer & [147] \\
\hline circPIP5K1A & miR-600 & SNAIL (indirectly by HIF- $1 \alpha$ ) & non-small cell lung cancer & [148] \\
\hline circ_0026344 & miR-183 & SNAIL (indirectly) & colorectal cancer & [149] \\
\hline
\end{tabular}




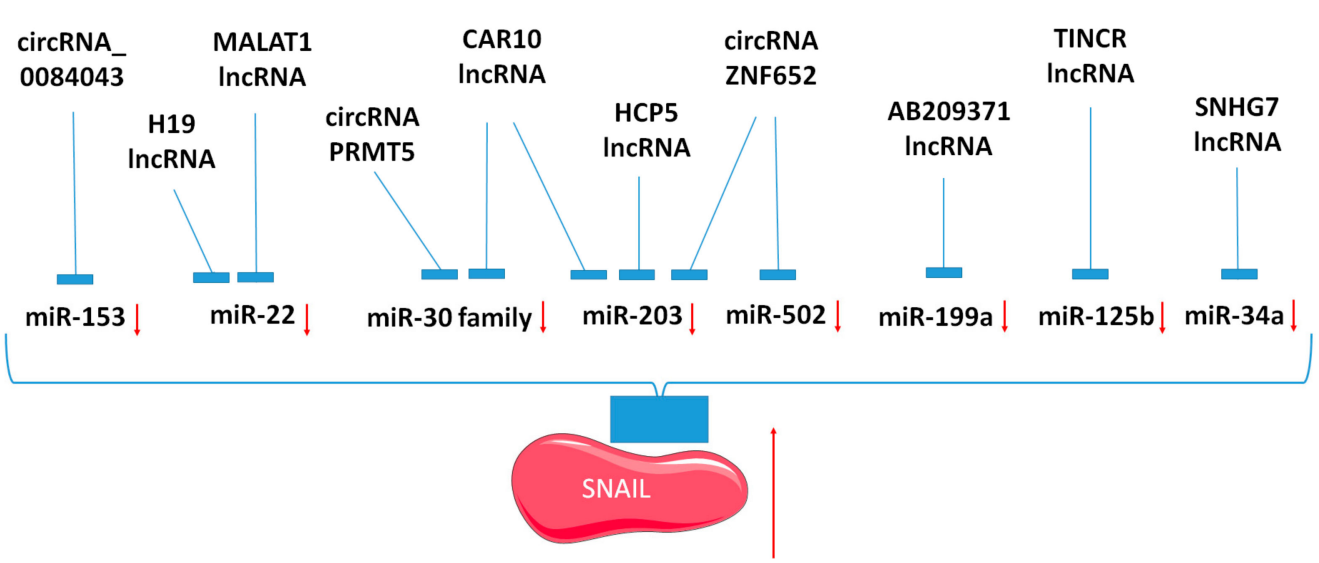

Figure 3. Role of long non-coding RNAs and circular RNAs as sponges for microRNAs in the regulation of SNAIL expression in tumors.

\section{SNAIL Regulation of Non-Coding RNAs}

MiRNAs were presented as regulators of SNAIL expression. On the other hand, there are several cases describing SNAIL as a regulator of miRNA level with implications to epithelial tumor progression and the role of EMT in this process. MiRNAs may be regulated either indirectly or by the direct binding of SNAIL to E-box sequences in miRNA promoters or regulatory sequences.

For example, in breast cancer cells, SNAIL directly suppresses miR-182 [88] and miR-203 [86]. In head and neck cancers, SNAIL binds to the miR-493 promoter [150]. SNAIL also significantly represses the miR-145 promoter. miR-145 plays a role in antagonizing SNAIL-mediated stemness in colorectal cancer [151]. In gastric cancer, SNAIL binds to the putative promoter of miR-375 [152]. SNAIL directly activates the transcription of miR-21 to produce exosomes abundant in miR-21, which promotes the M2-like polarization of tumor-associated macrophages [153].

In non-epithelial tumor types, such as glioma, SNAIL suppresses miR-128b expression by direct binding to the miR-128b-specific promoter motif; then, miR-128 and SP1 regulate tumor progression [154]. A similar direct mechanism was demonstrated for miR-128-2 in mammary epithelial cells. The loss of SNAIL-regulated miR-128-2 targets multiple stem cell factors to promote the oncogenic transformation of mammary epithelial cells [155]. The SNAIL/miR-128 axis regulates the growth, invasion, metastasis, and EMT of gastric cancer. miR-128 targets directly Bmi11, and it can reverse EMT induced by Bmi-1 via the PI3K/AKT pathway, whereas SNAIL curbs the expression of miR-128, and then down-regulated miR-128 promotes the expression of Bmi-1 [156]. The loss of SNAIL was also shown to inhibit cellular growth and metabolism through the miR-128-mediated signaling pathway in prostate cancer cells [157].

Interestingly, SNAIL may also exert its effects by epigenetic modifications. SNAIL is involved in CpG DNA methylation of the miR-200f loci, which is essential for maintenance of the mesenchymal phenotype. In the MDCK (Madin-Darby canine kidney) epithelial kidney cells model, it has been shown that ZEB1 and SNAIL engage miR-200f transcriptional and epigenetic regulation during EMT [158]. Regulation of the miR-200 family by SNAIL also plays a role in vasculogenesis and may be significant both in malignant cancer and in early developing embryos [159].

SNAIL overexpression increases the level of miR-125b through the SNAIL-activated $\mathrm{Wnt} / \beta$-catenin/TCF4 (transcription factor 4 ) axis. This mechanism was described for SNAIL-induced stem cell propagation [160]. Another example of SNAIL action in cancer stem cells is signaling axis involving SNAIL, miR-146a, and Numb in regulation of the switch between symmetric and asymmetric cell division in colorectal cancer stem cells [161].

As indicated previously, SNAIL is a regulator of not only EMT and cancer stem cells, but also of myogenic differentiation. In rhabdomyosarcoma, SNAIL regulates the expression of myogenic-associated miRNAs, such as miR-1, miR-206, and miR-378 [14]. What is more, the 
SNAIL/miR-199a-5p axis promotes the differentiation of fibroblasts into myofibroblasts by the induction of endothelial-mesenchymal transition [162].

There are also examples of interaction among lncRNAs, miRNAs, and SNAIL. SNAIL binds to the promoter of lncRNA PCA3 and activates its expression. Then, IncRNA PCA3 inhibits the translation of PRKD3 (serine/threonine-protein kinase D3) protein via competitive miR-1261 sponging and in that way promotes the invasion of prostate cancer cells [163].

SNAIL's role has been also described in controlling telomere transcription and integrity, which may be significant features of cancer stem cells, since telomere maintenance is essential for stemness. SNAIL turned out to be a negative regulator of IncRNA that controls telomere integrity, which is called telomeric repeat-containing RNA (TERRA). What is more, TERRA can also affect the transcription of some genes induced during EMT [164].

SNAIL may also not only regulate the level of lncRNAs, but it may also interact with them to modify the chromatin. IncRNA HOTAIR (HOX Transcript Antisense Intergenic RNA) mediates a physical interaction between SNAIL and EZH2 (enhancer of zeste homolog 2), which is an enzymatic subunit of the polycomb-repressive complex 2. In that way, SNAIL recruits EZH2 to specific genomic sites during EMT [165].

SNAIL may also regulate circRNAs. For example, SNAIL targets the E-box motif on the promoter of circ-ZNF652 to increase its expression [96].

Besides SNAIL, similar mechanisms of binding to miRNA promoters were also described for SLUG. In colorectal cancer, SLUG binds to miR-145 promoter and represses it to modulate 5-fluorouracil sensitivity [166]. In lung cancer cells, SLUG binds directly to the E-box in the promoter of miR-137 and acts as an activator, which promotes cancer invasion and progression by directly suppressing TFAP2C (transcription factor AP-2 gamma) [167]. In prostate cancer, SLUG is a direct repressor of miR-1 and miR-200 transcription [168]. In breast cancer cells, SLUG directly binds to miR-203 promoter, downregulating its expression [124]. SLUG-upregulated miR-221 promotes breast cancer progression through suppressing E-cadherin expression, which indicates that miR-221 is an additional blocker of E-cadherin besides SNAIL and SLUG [169].

Sometimes, both SNAIL and SLUG collaborate on EMT and tumor metastasis through miRNAs. In oral tongue squamous cell carcinoma, those transcription factors act through the miR-101-mediated EZH2 axis [170]. miR-101 functions as a tumor suppressor by directly targeting ZEB1 (zinc finger E-Box binding homeobox 1) in various cancers, including colorectal cancer [171].

To summarize, SNAIL and SLUG may be direct or indirect regulators of miRNAs, lncRNAs, and circRNAs (Table 5). There are several examples of direct binding SNAIL to promoters or regulatory sequences of non-coding RNAs (Figure 4). Subsequently, those RNAs target plenty of genes to regulate tumor progression.

Table 5. Non-coding RNAs regulated by SNAIL and SLUG.

\begin{tabular}{cccc}
\hline Non-Coding RNA & Mechanism & Cancer/Cell Type & References \\
\hline miR-1 & SLUG binding to promoter & prostate cancer & {$[168]$} \\
\hline miR-21 & $\begin{array}{c}\text { regulation by SNAIL } \\
\text { (unknown mechanism) }\end{array}$ & rhabdomyosarcoma & {$[14]$} \\
\hline miR-101 & SNAIL binding to promoter & head and neck cancer & {$[153]$} \\
\hline miR-125b & $\begin{array}{c}\text { transcriptional control by } \\
\text { SNAIL and SLUG }\end{array}$ & squamous cell carcinoma & {$[170]$} \\
\hline & $\begin{array}{c}\text { SNAIL-activated } \\
\text { Wnt/ } \beta \text {-catenin/TCF4 axis }\end{array}$ & breast cancer stem cells & {$[160]$} \\
\hline
\end{tabular}


Table 5. Cont.

\begin{tabular}{|c|c|c|c|}
\hline Non-Coding RNA & Mechanism & Cancer/Cell Type & References \\
\hline \multirow{3}{*}{ miR-128 } & \multirow{3}{*}{ SNAIL binding to promoter } & glioma & [154] \\
\hline & & prostate cancer & [157] \\
\hline & & gastric cancer & [156] \\
\hline miR-137 & SLUG binding to promoter & lung cancer & [167] \\
\hline \multirow[t]{2}{*}{ miR-145 } & SNAIL binding to promoter & colorectal cancer & [151] \\
\hline & SLUG binding to promoter & colorectal cancer & [166] \\
\hline miR-146a & $\begin{array}{c}\text { SNAIL-induced } \\
\beta \text {-catenin-TCF4 complex }\end{array}$ & colorectal cancer stem cells & [161] \\
\hline miR-182 & SNAIL binding to promoter & breast cancer & [88] \\
\hline \multirow[t]{2}{*}{ miR-200 } & $\begin{array}{l}\text { SNAIL involved in CpG DNA } \\
\text { methylation }\end{array}$ & human kidney cells & [158] \\
\hline & SLUG binding to promoter & prostate cancer & [168] \\
\hline \multirow[t]{2}{*}{ miR-203 } & SNAIL binding to promoter & breast cancer & [86] \\
\hline & SLUG binding to promoter & breast cancer & [124] \\
\hline miR-206 & $\begin{array}{l}\text { regulation by SNAIL } \\
\text { (unknown mechanism) }\end{array}$ & rhabdomyosarcoma & [14] \\
\hline miR-221 & $\begin{array}{l}\text { transcriptional control by } \\
\text { SLUG }\end{array}$ & breast cancer & [169] \\
\hline miR-375 & SNAIL binding to promoter & gastric cancer & [152] \\
\hline $\operatorname{miR}-378$ & $\begin{array}{l}\text { regulation by SNAIL } \\
\text { (unknown mechanism) }\end{array}$ & rhabdomyosarcoma & [14] \\
\hline $\operatorname{miR}-493$ & SNAIL binding to promoter & head and neck cancer & [150] \\
\hline lncRNA PCA3 & SNAIL binding to promoter & prostate cancer & [163] \\
\hline lncRNA TERRA & $\begin{array}{l}\text { transcriptional control by } \\
\text { SNAIL }\end{array}$ & $\begin{array}{l}\text { mesenchymal stem cells and } \\
\text { mammary cells }\end{array}$ & [164] \\
\hline lncRNA HOTAIR & $\begin{array}{l}\text { interaction of SNAIL with } \\
\text { HOTAIR and EZH2 }\end{array}$ & hepatocytes & [165] \\
\hline circ-ZNF652 & SNAIL binding to promoter & hepatocellular carcinoma & [96] \\
\hline
\end{tabular}

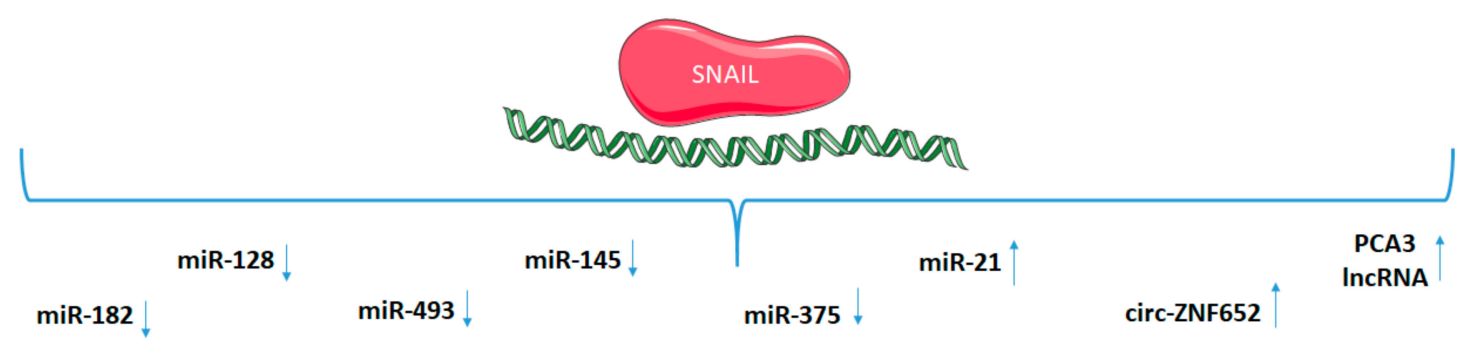

Figure 4. MiRNAs, long non-coding RNAs (lncRNAs), and circular RNAs regulated directly by SNAIL transcription factor.

\section{Multi-Component Feedback Loops and Multi-Component Signaling Networks}

The literature also describes several examples of multi-component feedback loops and multi-component signaling networks involving the SNAIL transcription factor and non-coding RNAs.

Selected different multi-component feedback loops and multi-component signaling networks are presented in Figure 5. 
An interesting example is miR-182, which is directly suppressed by SNAIL in breast cancer cells, which can also target its suppressor (Figure 5A). This mechanism regulates an epithelial-like phenotype in vitro and enhances macrometastases in vivo [88].

Similarly in breast cancer, miR-203 forms also a double-negative miR-203/SNAIL feedback loop, as SNAIL reduces the activity of the miR-203 promoter (Figure 5B) [86].

Moreover, miR-34 and SNAIL form a double-negative feedback loop (Figure 5C) [73] that may feed-forward regulate ZNF281/ZBP99 to promote EMT, which has implications for human colon and breast cancer [172]. The expression of ZNF281 (zinc finger protein 281) is induced by SNAIL and inhibited by miR-34a, which mediates the repression of ZNF281 by the p53 tumor suppressor. The deregulation of this circuitry by mutational and epigenetic alterations in the p53/miR-34a axis promotes colorectal cancer metastasis [173].

In head and neck cancers, SNAIL binds to miR-493 promoter to repress it, and subsequently, miR-493 forms a negative feedback loop with the insulin-like growth factor 1 receptor pathway to block tumorigenesis (Figure 5D) [150].

Besides miRNAs, SNAIL may also form feedback loops with circular RNAs. SNAIL upregulates circ-ZNF652 by binding to the E-box motif on the promoter. Subsequently, circ-ZNF652 acts a sponge for miR-203 and miR-502-5p, which target SNAIL 3'UTR (Figure 5E) [96].

In cancer stem cells, SNAIL forms a feedback circuit to maintain Wnt activity. SNAIL induces miR-146a expression through the $\beta$-catenin-TCF4 complex, and subsequently, miR-146a targets Numb to stabilize $\beta$-catenin (Figure 5F) [161].

An interesting example is also SNAIL action in ZEB1 circuit in melanoma cells. SNAIL is considered as an external signal that transcriptionally regulates the ZEB1/miR-200a/cicrZEB1 axis. circZEB1, generated from the ZEB1 gene, contains a binding site for mir200a, which is a post-transcriptional regulator of ZEB1 (Figure 5G) [174].

SLUG and microRNAs may also form regulatory loops. In breast cancer cells, SLUG and miR-203 form a double-negative feedback loop and SLUG directly binds to miR-203 promoter, downregulating its expression in metastatic breast cancer cells (Figure 5H) [124]. Furthermore, SLUG and miR-1/miR-200 act in a self-reinforcing regulatory loop, which results in EMT amplification (Figure 5I) [168].

What is also interesting is that sometimes, gene transcripts may also act as a competitive endogenous RNA (ceRNA) to regulate biological processes. FN1 (fibronectin 1) acts as a ceRNA for miR-200c in the canonical SNAIL-ZEB-miR200 pathway in breast cancer cells (Figure 5J), whereas TGFBI (transforming growth factor-beta-induced) is a transcript that is highly induced during EMT in lung cancer cells, which acts as the ceRNA for miR-21 to modulate EMT [175]. 

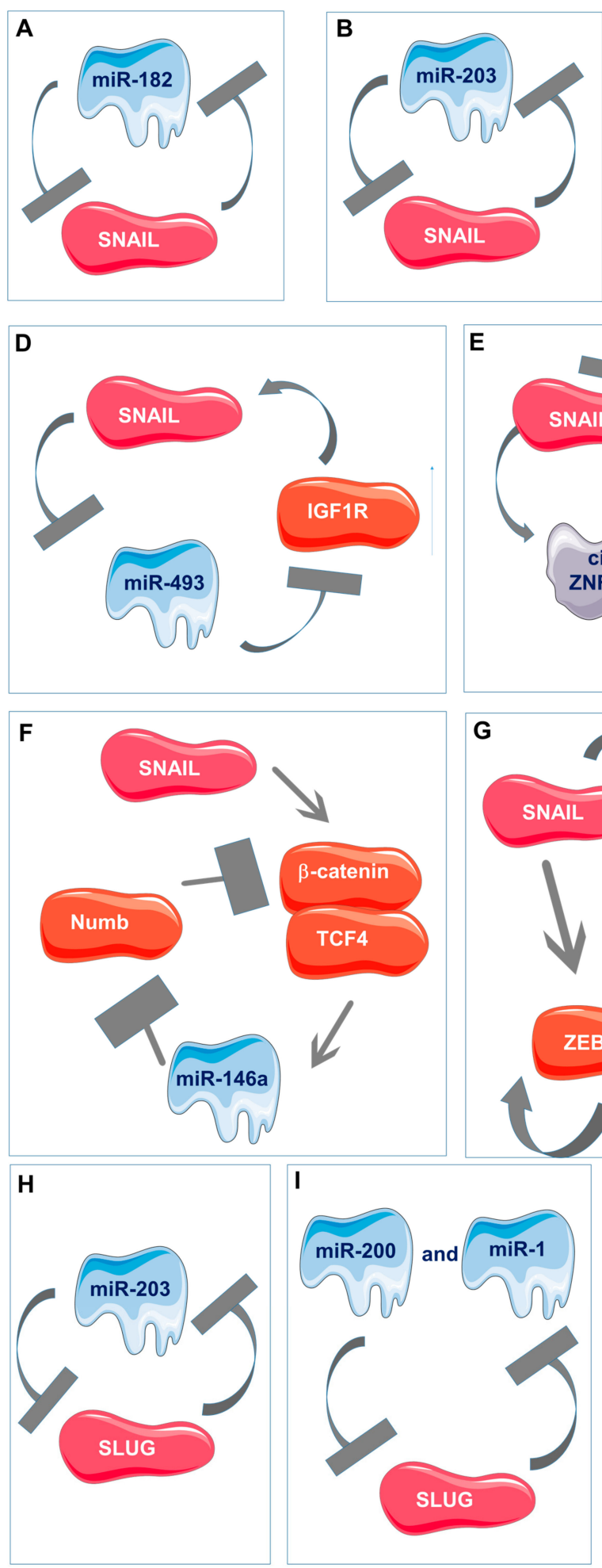

G
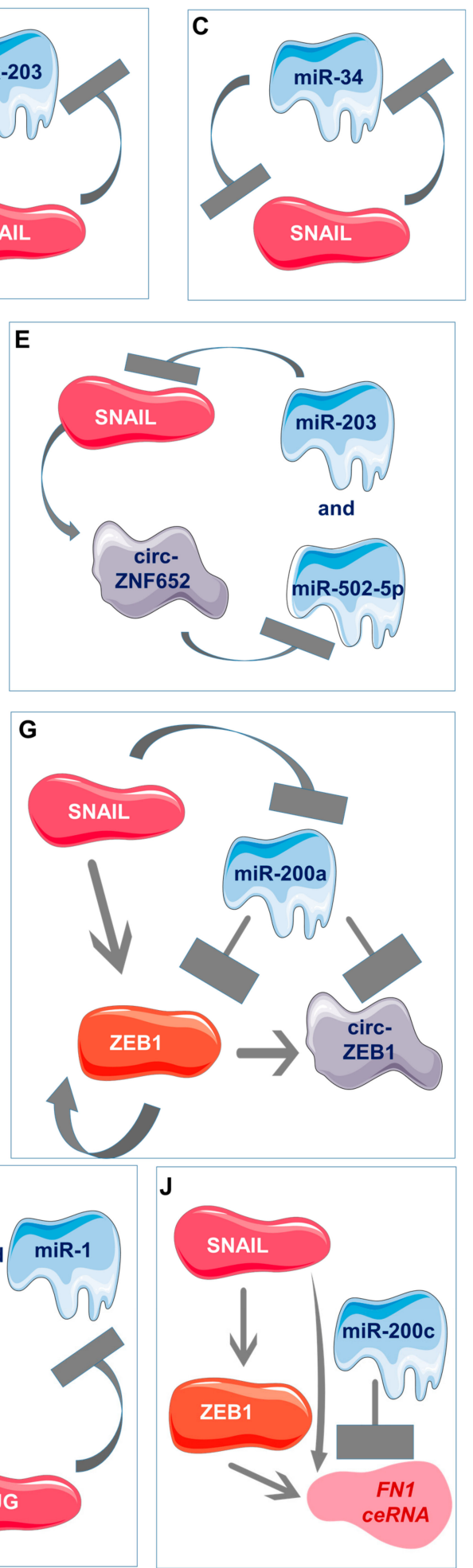

Figure 5. Multi-component feedback loops and multi-component signaling networks involving SNAIL and non-coding RNAs. (A) Negative regulation between SNAIL and miR-182. (B) Negative regulation between SNAIL and miR-203. (C) Negative regulation between SNAIL and miR-34. (D) Feedback loop between SNAIL, miR-493, and IGF1R. (E) Feedback loop between SNAIL, circ-ZNF652, miR-203, and miR-502-5p. (F) Signaling pathway involving SNAIL, $\beta$-catenin, miR-146a, and Numb. (G) Signaling pathway involving SNAIL, ZEB1, miR-200a, and circ-ZEB1. (H) Negative regulation between SLUG and miR-203. (I) Negative regulation among SLUG, miR-1, and miR-200. (J) Signaling pathway involving SNAIL, ZEB1, miR-200c, and FN1 ceRNA. 


\section{Conclusions}

SNAIL participates in many physiological and pathological processes, including embryonic development and cancer metastasis. Therefore, the identification of its crosstalk with non-coding RNAs can help in understanding the complex signaling networks that drive tumor progression. Unraveling these signaling networks may help generate new types of cancer therapeutics. miRNAs and other non-coding RNAs play key roles in tumor progression or suppression. One miRNA may target multiple genes besides SNAIL. Therapies targeting miRNA may enable the regulation of more than one signaling pathway. An interesting example of miRNA (described in this review) therapeutics is a drug based on miR-34a mimics, which has been already enrolled in clinical trials [176]. The identification of miRNA downstream and upstream of SNAIL may create novel possibilities for biomarker determination during cancer progression, which may lead to improvements in prognosis and therapy. As those miRNAs usually regulate epithelial to mesenchymal transition, their identification may help to distinguish different stages of tumor development, as well as benign and malignant tumors. For the identification of novel biomarkers, the next step is verification of whether miRNA candidates can be secreted from tumor to blood vessels.

Funding: This research was funded by the National Science Centre in Poland to K.S.: 2015/17/D/NZ5/02202 and to M.M.: 2013/09/B/NZ5/00769.

Acknowledgments: K.S. was a recipient of the Foundation for Polish Science's START scholarship for outstanding young scientists and the Polish Ministry of Science and Higher Education's scholarship for outstanding young scientists.

Conflicts of Interest: The authors declare no conflict of interest.

\section{References}

1. Alberga, A.; Boulay, J.L.; Kempe, E.; Dennefeld, C.; Haenlin, M. The snail gene required for mesoderm formation in Drosophila is expressed dynamically in derivatives of all three germ layers. Development 1991, 111, 983-992. [PubMed]

2. Nieto, M.A. The snail superfamily of zinc-finger transcription factors. Nat. Rev. Mol. Cell Biol. 2002, 3, 155-166. [CrossRef] [PubMed]

3. Wang, Y.; Shi, J.; Chai, K.; Ying, X.; Zhou, B.P. The Role of Snail in EMT and Tumorigenesis. Curr. Cancer Drug Targets 2013, 13, 963-972. [CrossRef] [PubMed]

4. Barberà, M.J.; Puig, I.; Domínguez, D.; Julien-Grille, S.; Guaita-Esteruelas, S.; Peiró, S.; Baulida, J.; Francí, C.; Dedhar, S.; Larue, L.; et al. Regulation of Snail transcription during epithelial to mesenchymal transition of tumor cells. Oncogene 2004, 23, 7345-7354. [CrossRef] [PubMed]

5. De Craene, B.; van Roy, F.; Berx, G. Unraveling signalling cascades for the Snail family of transcription factors. Cell. Signal. 2005, 17, 535-547. [CrossRef] [PubMed]

6. Zhou, B.P.; Deng, J.; Xia, W.; Xu, J.; Li, Y.M.; Gunduz, M.; Hung, M.-C. Dual regulation of Snail by GSK-3 $\beta$-mediated phosphorylation in control of epithelial-mesenchymal transition. Nat. Cell Biol. 2004, 6, 931-940. [CrossRef]

7. Peinado, H.; del Carmen Iglesias-de la Cruz, M.; Olmeda, D.; Csiszar, K.; Fong, K.S.K.; Vega, S.; Nieto, M.A.; Cano, A.; Portillo, F. A molecular role for lysyl oxidase-like 2 enzyme in Snail regulation and tumor progression. EMBO J. 2005, 24, 3446-3458. [CrossRef]

8. Viñas-Castells, R.; Beltran, M.; Valls, G.; Gómez, I.; García, J.M.; Montserrat-Sentís, B.; Baulida, J.; Bonilla, F.; de Herreros, A.G.; Díaz, V.M. The Hypoxia-controlled FBXL14 Ubiquitin Ligase Targets SNAIL1 for Proteasome Degradation. J. Biol. Chem. 2010, 285, 3794-3805. [CrossRef]

9. Park, S.Y.; Kim, H.S.; Kim, N.H.; Ji, S.; Cha, S.Y.; Kang, J.G.; Ota, I.; Shimada, K.; Konishi, N.; Nam, H.W.; et al. Snail1 is stabilized by O-GlcNAc modification in hyperglycaemic condition. EMBO J. 2010, 29, 3787-3796. [CrossRef]

10. Wu, Y.; Deng, J.; Rychahou, P.G.; Qiu, S.; Evers, B.M.; Zhou, B.P. Stabilization of Snail by NF-kB Is Required for Inflammation-Induced Cell Migration and Invasion. Cancer Cell 2009, 15, 416-428. [CrossRef] 
11. Yang, Z.; Rayala, S.; Nguyen, D.; Vadlamudi, R.K.; Chen, S.; Kumar, R. Pak1 Phosphorylation of Snail, a Master Regulator of Epithelial-to-Mesenchyme Transition, Modulates Snail's Subcellular Localization and Functions. Cancer Res. 2005, 65, 3179-3184. [CrossRef] [PubMed]

12. Peinado, H.; Olmeda, D.; Cano, A. Snail, Zeb and bHLH factors in tumour progression: An alliance against the epithelial phenotype? Nat. Rev. Cancer 2007, 7, 415-428. [CrossRef] [PubMed]

13. Peinado, H.; Ballestar, E.; Esteller, M.; Cano, A. Snail mediates E-cadherin repression by the recruitment of the Sin3A/histone deacetylase 1 (HDAC1)/HDAC2 complex. Mol. Cell. Biol. 2004, 24, 306-319. [CrossRef] [PubMed]

14. Skrzypek, K.; Kusienicka, A.; Trzyna, E.; Szewczyk, B.; Ulman, A.; Konieczny, P.; Adamus, T.; Badyra, B.; Kortylewski, M.; Majka, M. SNAIL is a key regulator of alveolar rhabdomyosarcoma tumor growth and differentiation through repression of MYF5 and MYOD function. Cell Death Dis. 2018, 9, 643. [CrossRef] [PubMed]

15. Soleimani, V.D.; Yin, H.; Jahani-Asl, A.; Ming, H.; Kockx, C.E.M.; van Ijcken, W.F.J.; Grosveld, F.; Rudnicki, M.A. Snail regulates $\mathrm{MyoD}$ binding-site occupancy to direct enhancer switching and differentiation-specific transcription in myogenesis. Mol. Cell 2012, 47, 457-468. [CrossRef] [PubMed]

16. Barrallo-Gimeno, A.; Nieto, M.A. The Snail genes as inducers of cell movement and survival: Implications in development and cancer. Development 2005, 132, 3151-3161. [CrossRef] [PubMed]

17. Peiro, S.; Escrivà, M.; Puig, I.; Barberà, M.J.; Dave, N.; Herranz, N.; Larriba, M.J.; Takkunen, M.; Francí, C.; Muñoz, A.; et al. Snail1 transcriptional repressor binds to its own promoter and controls its expression. Nucleic Acids Res. 2006, 34, 2077-2084. [CrossRef]

18. Sakai, D.; Suzuki, T.; Osumi, N.; Wakamatsu, Y. Cooperative action of Sox9, Snail2 and PKA signaling in early neural crest development. Development 2006, 133, 1323-1333. [CrossRef]

19. Sundararajan, V.; Tan, M.; Tan, T.Z.; Ye, J.; Thiery, J.P.; Huang, R.Y.-J. SNAI1 recruits HDAC1 to suppress SNAI2 transcription during epithelial to mesenchymal transition. Sci. Rep. 2019, 9, 8295. [CrossRef]

20. Alidadiani, N.; Ghaderi, S.; Dilaver, N.; Bakhshamin, S.; Bayat, M. Epithelial mesenchymal transition Transcription Factor (TF): The structure, function and microRNA feedback loop. Gene 2018, 674, 115-120. [CrossRef]

21. Yamamura, S.; Imai-Sumida, M.; Tanaka, Y.; Dahiya, R. Interaction and cross-talk between non-coding RNAs. Cell. Mol. Life Sci. 2018, 75, 467-484. [CrossRef] [PubMed]

22. Bánfai, B.; Jia, H.; Khatun, J.; Wood, E.; Risk, B.; Gundling, W.E.; Kundaje, A.; Gunawardena, H.P.; Yu, Y.; Xie, L.; et al. Long noncoding RNAs are rarely translated in two human cell lines. Genome Res. 2012, 22, 1646-1657. [CrossRef] [PubMed]

23. Guttman, M.; Amit, I.; Garber, M.; French, C.; Lin, M.F.; Feldser, D.; Huarte, M.; Zuk, O.; Carey, B.W.; Cassady, J.P.; et al. Chromatin signature reveals over a thousand highly conserved large non-coding RNAs in mammals. Nature 2009, 458, 223-227. [CrossRef] [PubMed]

24. Quinn, J.J.; Chang, H.Y. Unique features of long non-coding RNA biogenesis and function. Nat. Rev. Genet. 2016, 17, 47-62. [CrossRef] [PubMed]

25. Sigova, A.A.; Mullen, A.C.; Molinie, B.; Gupta, S.; Orlando, D.A.; Guenther, M.G.; Almada, A.E.; Lin, C.; Sharp, P.A.; Giallourakis, C.C.; et al. Divergent transcription of long noncoding RNA/mRNA gene pairs in embryonic stem cells. Proc. Natl. Acad. Sci. USA 2013, 110, 2876-2881. [CrossRef] [PubMed]

26. Zheng, G.X.Y.; Do, B.T.; Webster, D.E.; Khavari, P.A.; Chang, H.Y. Dicer-microRNA-Myc circuit promotes transcription of hundreds of long noncoding RNAs. Nat. Struct. Mol. Biol. 2014, 21, 585-590. [CrossRef] [PubMed]

27. Dhir, A.; Dhir, S.; Proudfoot, N.J.; Jopling, C.L. Microprocessor mediates transcriptional termination of long noncoding RNA transcripts hosting microRNAs. Nat. Struct. Mol. Biol. 2015, 22, 319-327. [CrossRef]

28. Chi, Y.; Wang, D.; Wang, J.; Yu, W.; Yang, J. Long Non-Coding RNA in the Pathogenesis of Cancers. Cells 2019, 8, 1015. [CrossRef]

29. Conn, S.J.; Pillman, K.A.; Toubia, J.; Conn, V.M.; Salmanidis, M.; Phillips, C.A.; Roslan, S.; Schreiber, A.W.; Gregory, P.A.; Goodall, G.J. The RNA binding protein quaking regulates formation of circRNAs. Cell 2015, 160, 1125-1134. [CrossRef]

30. Zhang, Y.; Zhang, X.O.; Chen, T.; Xiang, J.F.; Yin, Q.F.; Xing, Y.H.; Zhu, S.; Yang, L.; Chen, L.L. Circular Intronic Long Noncoding RNAs. Mol. Cell 2013, 51, 792-806. [CrossRef] 
31. Li, Z.; Huang, C.; Bao, C.; Chen, L.; Lin, M.; Wang, X.; Zhong, G.; Yu, B.; Hu, W.; Dai, L.; et al. Exon-intron circular RNAs regulate transcription in the nucleus. Nat. Struct. Mol. Biol. 2015, 22, 256-264. [CrossRef] [PubMed]

32. Su, Y.; Zhong, G.; Jiang, N.; Huang, M.; Lin, T. Circular RNA, a novel marker for cancer determination. Int. J. Mol. Med. 2018, 42, 1786-1798. [CrossRef] [PubMed]

33. Schneider, T.; Bindereif, A. Circular RNAs: Coding or noncoding? Cell Res. 2017, 27, 724-725. [CrossRef] [PubMed]

34. Vasudevan, S.; Tong, Y.; Steitz, J.A. Switching from Repression to Activation: MicroRNAs Can Up-Regulate Translation. Science 2007, 318, 1931-1934. [CrossRef] [PubMed]

35. Stavast, C.J.; Erkeland, S.J. The Non-Canonical Aspects of MicroRNAs: Many Roads to Gene Regulation. Cells 2019, 8, 1465. [CrossRef]

36. Jing, Q.; Huang, S.; Guth, S.; Zarubin, T.; Motoyama, A.; Chen, J.; Di Padova, F.; Lin, S.-C.; Gram, H.; Han, J. Involvement of microRNA in AU-rich element-mediated mRNA instability. Cell 2005, 120, 623-634. [CrossRef]

37. Lim, L.P.; Lau, N.C.; Weinstein, E.G.; Abdelhakim, A.; Yekta, S.; Rhoades, M.W.; Burge, C.B.; Bartel, D.P. The microRNAs of Caenorhabditis elegans. Genes Dev. 2003, 17, 991-1008. [CrossRef]

38. Grimson, A.; Farh, K.K.-H.; Johnston, W.K.; Garrett-Engele, P.; Lim, L.P.; Bartel, D.P. MicroRNA targeting specificity in mammals: Determinants beyond seed pairing. Mol. Cell 2007, 27, 91-105. [CrossRef]

39. Nielsen, C.B.; Shomron, N.; Sandberg, R.; Hornstein, E.; Kitzman, J.; Burge, C.B. Determinants of targeting by endogenous and exogenous microRNAs and siRNAs. RNA 2007, 13, 1894-1910. [CrossRef]

40. Baskerville, S.; Bartel, D.P. Microarray profiling of microRNAs reveals frequent coexpression with neighboring miRNAs and host genes. RNA 2005, 11, 241-247. [CrossRef]

41. Lin, S.-L.; Miller, J.D.; Ying, S.-Y. Intronic MicroRNA (miRNA). J. Biomed. Biotechnol. 2006, 2006, 26818. [CrossRef] [PubMed]

42. Treiber, T.; Treiber, N.; Meister, G. Regulation of microRNA biogenesis and its crosstalk with other cellular pathways. Nat. Rev. Mol. Cell Biol. 2019, 20, 5-20. [CrossRef] [PubMed]

43. Lee, Y.; Jeon, K.; Lee, J.-T.; Kim, S.; Kim, V.N. MicroRNA maturation: Stepwise processing and subcellular localization. EMBO J. 2002, 21, 4663-4670. [CrossRef] [PubMed]

44. Lewis, B.P.; Shih, I.; Jones-Rhoades, M.W.; Bartel, D.P.; Burge, C.B. Prediction of Mammalian MicroRNA Targets. Cell 2003, 115, 787-798. [CrossRef]

45. Calin, G.A.; Dumitru, C.D.; Shimizu, M.; Bichi, R.; Zupo, S.; Noch, E.; Aldler, H.; Rattan, S.; Keating, M.; Rai, K.; et al. Frequent deletions and down-regulation of micro- RNA genes miR15 and miR16 at 13q14 in chronic lymphocytic leukemia. Proc. Natl. Acad. Sci. USA 2002, 99, 15524-15529. [CrossRef]

46. Michael, M.Z.; O'Connor, S.M.; van Holst Pellekaan, N.G.; Young, G.P.; James, R.J. Reduced accumulation of specific microRNAs in colorectal neoplasia. Mol. Cancer Res. 2003, 1, 882-891.

47. Ciesla, M.; Skrzypek, K.; Kozakowska, M.; Loboda, A.; Jozkowicz, A.; Dulak, J. MicroRNAs as biomarkers of disease onset. Anal. Bioanal. Chem. 2011, 401, 2051-2061. [CrossRef]

48. Lu, J.; Getz, G.; Miska, E.A.; Alvarez-Saavedra, E.; Lamb, J.; Peck, D.; Sweet-Cordero, A.; Ebert, B.L.; Mak, R.H.; Ferrando, A.A.; et al. MicroRNA expression profiles classify human cancers. Nature 2005, 435, 834-838. [CrossRef]

49. Lin, S.; Gregory, R.I. MicroRNA biogenesis pathways in cancer. Nat. Rev. Cancer 2015, 15, 321-333. [CrossRef]

50. Sandberg, R.; Neilson, J.R.; Sarma, A.; Sharp, P.A.; Burge, C.B. Proliferating cells express mRNAs with shortened 3' untranslated regions and fewer microRNA target sites. Science 2008, 320, 1643-1647. [CrossRef]

51. Calin, G.A.; Sevignani, C.; Dumitru, C.D.; Hyslop, T.; Noch, E.; Yendamuri, S.; Shimizu, M.; Rattan, S.; Bullrich, F.; Negrini, M.; et al. Human microRNA genes are frequently located at fragile sites and genomic regions involved in cancers. Proc. Natl. Acad. Sci. USA 2004, 101, 2999-3004. [CrossRef] [PubMed]

52. Hayashita, Y.; Osada, H.; Tatematsu, Y.; Yamada, H.; Yanagisawa, K.; Tomida, S.; Yatabe, Y.; Kawahara, K.; Sekido, Y.; Takahashi, T. A polycistronic microRNA cluster, miR-17-92, is overexpressed in human lung cancers and enhances cell proliferation. Cancer Res. 2005, 65, 9628-9632. [CrossRef] [PubMed]

53. Fang, L.L.; Wang, X.H.; Sun, B.F.; Zhang, X.D.; Zhu, X.H.; Yu, Z.J.; Luo, H. Expression, regulation and mechanism of action of the miR-17-92 cluster in tumor cells. Int. J. Mol. Med. 2017, 40, 1624-1630. [CrossRef] [PubMed] 
54. Shi, L.; Cheng, Z.; Zhang, J.; Li, R.; Zhao, P.; Fu, Z.; You, Y. hsa-mir-181a and hsa-mir-181b function as tumor suppressors in human glioma cells. Brain Res. 2008, 1236, 185-193. [CrossRef] [PubMed]

55. Gao, W.; Yu, Y.; Cao, H.; Shen, H.; Li, X.; Pan, S.; Shu, Y. Deregulated expression of miR-21, miR-143 and miR-181a in non small cell lung cancer is related to clinicopathologic characteristics or patient prognosis. Biomed. Pharmacother. 2010, 64, 399-408. [CrossRef]

56. Hagman, Z.; Larne, O.; Edsjö, A.; Bjartell, A.; Ehrnström, R.A.; Ulmert, D.; Lilja, H.; Ceder, Y. miR-34c is downregulated in prostate cancer and exerts tumor suppressive functions. Int. J. Cancer 2010, 127, 2768-2776. [CrossRef]

57. Dacic, S.; Kelly, L.; Shuai, Y.; Nikiforova, M.N. miRNA expression profiling of lung adenocarcinomas: Correlation with mutational status. Mod. Pathol. 2010, 23, 1577-1582. [CrossRef]

58. Collet, G.; Skrzypek, K.; Grillon, C.; Matejuk, A.; El Hafni-Rahbi, B.; Lamerant-Fayel, N.; Kieda, C. Hypoxia control to normalize pathologic angiogenesis: Potential role for endothelial precursor cells and miRNAs regulation. Vascul. Pharmacol. 2012, 56,1-10. [CrossRef]

59. Musavi Shenas, M.H.; Eghbal-Fard, S.; Mehrisofiani, V.; Abd Yazdani, N.; Rahbar Farzam, O.; Marofi, F.; Yousefi, M. MicroRNAs and signaling networks involved in epithelial-mesenchymal transition. J. Cell. Physiol. 2019, 234, 5775-5785. [CrossRef]

60. Subhra Das, S.; James, M.; Paul, S.; Chakravorty, N. miRnalyze: An interactive database linking tool to unlock intuitive microRNA regulation of cell signaling pathways. Database 2017, 2017, bax015. [CrossRef]

61. Li, J.; Yu, H.; Xi, M.; Ma, D.; Lu, X. The SNAI1 3'UTR functions as a sponge for multiple migration-/invasion-related microRNAs. Tumor Biol. 2015, 36, 1067-1072. [CrossRef] [PubMed]

62. Kumarswamy, R.; Mudduluru, G.; Ceppi, P.; Muppala, S.; Kozlowski, M.; Niklinski, J.; Papotti, M.; Allgayer, H. MicroRNA-30a inhibits epithelial-to-mesenchymal transition by targeting Snai1 and is downregulated in non-small cell lung cancer. Int. J. Cancer 2012, 130, 2044-2053. [CrossRef] [PubMed]

63. Xiao, B.; Shi, X.; Bai, J. miR-30a regulates the proliferation and invasion of breast cancer cells by targeting Snail. Oncol. Lett. 2018, 17, 406-413. [CrossRef] [PubMed]

64. Xiong, Y.; Wang, Y.; Wang, L.; Huang, Y.; Xu, Y.; Xu, L.; Guo, Y.; Lu, J.; Li, X.; Zhu, M.; et al. MicroRNA-30b targets Snail to impede epithelial-mesenchymal transition in pancreatic cancer stem cells. J. Cancer 2018, 9, 2147-2159. [CrossRef] [PubMed]

65. Noori, J.; Haghjooy Javanmard, S.; Sharifi, M. The role of microRNA-30a and downstream snail1 on the growth and metastasis of melanoma tumor. Iran. J. Basic Med. Sci. 2019, 22, 534-540. [PubMed]

66. Ma, T.; Zhao, Y.; Lu, Q.; Lu, Y.; Liu, Z.; Xue, T.; Shao, Y. MicroRNA-30c functions as a tumor suppressor via targeting SNAI1 in esophageal squamous cell carcinoma. Biomed. Pharmacother. 2018, 98, 680-686. [CrossRef] [PubMed]

67. Liu, Z.; Tu, K.; Liu, Q. Effects of microRNA-30a on migration, invasion and prognosis of hepatocellular carcinoma. FEBS Lett. 2014, 588, 3089-3097. [CrossRef]

68. Zhang, J.; Zhang, H.; Liu, J.; Tu, X.; Zang, Y.; Zhu, J.; Chen, J.; Dong, L.; Zhang, J. miR-30 inhibits TGF- $\beta 1$-induced epithelial-to-mesenchymal transition in hepatocyte by targeting Snail1. Biochem. Biophys. Res. Commun. 2012, 417, 1100-1105. [CrossRef]

69. Cheng, Y.; Zhou, M.; Zhou, W. MicroRNA-30e regulates TGF- $\beta$-mediated NADPH oxidase 4-dependent oxidative stress by Snai1 in atherosclerosis. Int. J. Mol. Med. 2019, 43, 1806-1816. [CrossRef]

70. Chang, C.-W.; Yu, J.-C.; Hsieh, Y.-H.; Yao, C.-C.; Chao, J.-I.; Chen, P.-M.; Hsieh, H.-Y.; Hsiung, C.-N.; Chu, H.-W.; Shen, C.-Y.; et al. MicroRNA-30a increases tight junction protein expression to suppress the epithelial-mesenchymal transition and metastasis by targeting Slug in breast cancer. Oncotarget 2016, 7, 16462-16478. [CrossRef]

71. Kim, N.H.; Kim, H.S.; Li, X.-Y.; Lee, I.; Choi, H.-S.; Kang, S.E.; Cha, S.Y.; Ryu, J.K.; Yoon, D.; Fearon, E.R.; et al. A p53/miRNA-34 axis regulates Snail1-dependent cancer cell epithelial-mesenchymal transition. J. Cell Biol. 2011, 195, 417-433. [CrossRef] [PubMed]

72. Dong, P.; Xiong, Y.; Watari, H.; Hanley, S.J.B.; Konno, Y.; Ihira, K.; Yamada, T.; Kudo, M.; Yue, J.; Sakuragi, N. MiR-137 and miR-34a directly target Snail and inhibit EMT, invasion and sphere-forming ability of ovarian cancer cells. J. Exp. Clin. Cancer Res. 2016, 35, 132. [CrossRef] [PubMed]

73. Siemens, H.; Jackstadt, R.; Hünten, S.; Kaller, M.; Menssen, A.; Götz, U.; Hermeking, H. miR-34 and SNAIL form a double-negative feedback loop to regulate epithelial-mesenchymal transitions. Cell Cycle 2011, 10, 4256-4271. [CrossRef] [PubMed] 
74. Tang, Y.; Tang, Y.; Cheng, Y. miR-34a inhibits pancreatic cancer progression through Snail1-mediated epithelial-mesenchymal transition and the Notch signaling pathway. Sci. Rep. 2017, 7, 38232. [CrossRef]

75. Zhang, B.; Fu, T.; Zhang, L. MicroRNA-153 suppresses human laryngeal squamous cell carcinoma migration and invasion by targeting the SNAI1 gene. Oncol. Lett. 2018, 16, 5075-5083. [CrossRef]

76. Zeng, H.F.; Yan, S.; Wu, S.F. MicroRNA-153-3p suppress cell proliferation and invasion by targeting SNAI1 in melanoma. Biochem. Biophys. Res. Commun. 2017, 487, 140-145. [CrossRef]

77. Zuo, J.; Wang, D.; Shen, H.; Liu, F.; Han, J.; Zhang, X. MicroRNA-153 inhibits tumor progression in esophageal squamous cell carcinoma by targeting SNAI1. Tumor Biol. 2016, 37, 16135-16140. [CrossRef]

78. Wang, Z.; Liu, C. MiR-153 regulates metastases of gastric cancer through Snail. Tumor Biol. 2016, 37, 15509-15515. [CrossRef]

79. Xia, W.; Ma, X.; Li, X.; Dong, H.; YI, J.; Zeng, W.; Yang, Z. miR-153 inhibits epithelial-to-mesenchymal transition in hepatocellular carcinoma by targeting Snail. Oncol. Rep. 2015, 34, 655-662. [CrossRef]

80. Bai, Z.; Sun, J.; Wang, X.; Wang, H.; Pei, H.; Zhang, Z. MicroRNA-153 is a prognostic marker and inhibits cell migration and invasion by targeting SNAI1 in human pancreatic ductal adenocarcinoma. Oncol. Rep. 2015, 34, 595-602. [CrossRef]

81. Zhang, K.; Li, X.Y.; Wang, Z.M.; Han, Z.F.; Zhao, Y.H. MiR-22 inhibits lung cancer cell EMT and invasion through targeting Snail. Eur. Rev. Med. Pharmacol. Sci. 2017, 21, 3598-3604. [PubMed]

82. Xu, M.; Li, J.; Wang, X.; Meng, S.; Shen, J.; Wang, S.; Xu, X.; Xie, B.; Liu, B.; Xie, L. MiR-22 suppresses epithelial-mesenchymal transition in bladder cancer by inhibiting Snail and MAPK1/Slug/vimentin feedback loop. Cell Death Dis. 2018, 9, 209. [CrossRef] [PubMed]

83. Luan, W.; Li, L.; Shi, Y.; Bu, X.; Xia, Y.; Wang, J.; Djangmah, H.S.; Liu, X.; You, Y.; Xu, B. Long non-coding RNA MALAT1 acts as a competing endogenous RNA to promote malignant melanoma growth and metastasis by sponging miR-22. Oncotarget 2016, 7, 63901-63912. [CrossRef]

84. Zuo, Q.-F.; Cao, L.-Y.; Yu, T.; Gong, L.; Wang, L.-N.; Zhao, Y.-L.; Xiao, B.; Zou, Q.-M. MicroRNA-22 inhibits tumor growth and metastasis in gastric cancer by directly targeting MMP14 and Snail. Cell Death Dis. 2015, 6, e2000. [CrossRef] [PubMed]

85. Dong, H.; Hu, J.; Zou, K.; Ye, M.; Chen, Y.; Wu, C.; Chen, X.; Han, M. Activation of LncRNA TINCR by H3K27 acetylation promotes Trastuzumab resistance and epithelial-mesenchymal transition by targeting MicroRNA-125b in breast Cancer. Mol. Cancer 2019, 18, 3. [CrossRef]

86. Moes, M.; Le Béchec, A.; Crespo, I.; Laurini, C.; Halavatyi, A.; Vetter, G.; Del Sol, A.; Friederich, E. A novel network integrating a miRNA-203/SNAI1 feedback loop which regulates epithelial to mesenchymal transition. PLOS ONE 2012, 7, e35440. [CrossRef]

87. Zhang, Y.-F.; Yu, Y.; Song, W.-Z.; Zhang, R.-M.; Jin, S.; Bai, J.-W.; Kang, H.-B.; Wang, X.; CaoO, X.-C. miR-410-3p suppresses breast cancer progression by targeting Snail. Oncol. Rep. 2016, 36, 480-486. [CrossRef]

88. Zhan, Y.; Li, X.; Liang, X.; Li, L.; Cao, B.; Wang, B.; Ma, J.; Ding, F.; Wang, X.; Pang, D.; et al. MicroRNA-182 drives colonization and macroscopic metastasis via targeting its suppressor SNAI1 in breast cancer. Oncotarget 2017, 8, 4629-4641. [CrossRef]

89. Yu, T.; Wang, L.; Li, W.; Zuo, Q.; Li, M.; Zou, Q.; Xiao, B. Downregulation of miR-491-5p promotes gastric cancer metastasis by regulating SNAIL and FGFR4. Cancer Sci. 2018, 109, 1393-1403. [CrossRef]

90. Liu, Z.; Long, J.; Du, R.; Ge, C.; Guo, K.; Xu, Y. miR-204 regulates the EMT by targeting snai1 to suppress the invasion and migration of gastric cancer. Tumor Biol. 2016, 37, 8327-8335. [CrossRef]

91. Suzuki, T.; Mizutani, K.; Minami, A.; Nobutani, K.; Kurita, S.; Nagino, M.; Shimono, Y.; Takai, Y. Suppression of the TGF- $\beta 1$-induced protein expression of SNAI1 and N-cadherin by miR-199a. Genes Cells 2014, 19, 667-675. [CrossRef] [PubMed]

92. Jiang, K.; Zhao, T.; Shen, M.; Zhang, F.; Duan, S.; Lei, Z.; Chen, Y. MiR-940 inhibits TGF- $\beta$-induced epithelial-mesenchymal transition and cell invasion by targeting Snail in non-small cell lung cancer. J. Cancer 2019, 10, 2735-2744. [CrossRef] [PubMed]

93. Ma, S.; Jia, W.; Ni, S. miR-199a-5p inhibits the progression of papillary thyroid carcinoma by targeting SNAI1. Biochem. Biophys. Res. Commun. 2018, 497, 181-186. [CrossRef] [PubMed]

94. Cao, L.; Wan, Q.; Li, F.; Tang, C.E. MiR-363 Inhibits Cisplatin Chemoresistance of Epithelial Ovarian Cancer by Regulating Snail-Induced Epithelial-Mesenchymal Transition. BMB Rep. 2018, 5, 456-461. [CrossRef] 
95. Jin, Y.; Wang, J.; Han, J.; Luo, D.; Sun, Z. MiR-122 inhibits epithelial-mesenchymal transition in hepatocellular carcinoma by targeting Snail1 and Snail2 and suppressing WNT/ $\beta$-cadherin signaling pathway. Exp. Cell Res. 2017, 360, 210-217. [CrossRef]

96. Guo, J.; Duan, H.; Li, Y.; Yang, L.; Yuan, L. A novel circular RNA circ-ZNF652 promotes hepatocellular carcinoma metastasis through inducing snail-mediated epithelial-mesenchymal transition by sponging miR-203/miR-502-5p. Biochem. Biophys. Res. Commun. 2019, 513, 812-819. [CrossRef]

97. Zhang, X.; Zhang, T.; Yang, K.; Zhang, M.; Wang, K. miR-486-5p suppresses prostate cancer metastasis by targeting Snail and regulating epithelial-mesenchymal transition. Onco. Targets. Ther. 2016, 9, 6909-6914. [CrossRef]

98. Wang, K.; Jin, W.; Jin, P.; Fei, X.; Wang, X.; Chen, X. miR-211-5p Suppresses Metastatic Behavior by Targeting SNAI1 in Renal Cancer. Mol. Cancer Res. 2017, 15, 448-456. [CrossRef]

99. Muraoka, N.; Yamakawa, H.; Miyamoto, K.; Sadahiro, T.; Umei, T.; Isomi, M.; Nakashima, H.; Akiyama, M.; Wada, R.; Inagawa, K.; et al. MiR-133 promotes cardiac reprogramming by directly repressing Snai1 and silencing fibroblast signatures. EMBO J. 2014, 33, 1565-1581. [CrossRef]

100. Bai, X.; Geng, J.; Zhou, Z.; Tian, J.; Li, X. MicroRNA-130b improves renal tubulointerstitial fibrosis via repression of Snail-induced epithelial-mesenchymal transition in diabetic nephropathy. Sci. Rep. 2016, 6, 20475. [CrossRef]

101. Zhang, J.-P.; Zeng, C.; Xu, L.; Gong, J.; Fang, J.-H.; Zhuang, S.-M. MicroRNA-148a suppresses the epithelial-mesenchymal transition and metastasis of hepatoma cells by targeting Met/Snail signaling. Oncogene 2014, 33, 4069-4076. [CrossRef] [PubMed]

102. Jia, Z.; Zhang, Y.; Xu, Q.; Guo, W.; Guo, A. miR-126 suppresses epithelial-to-mesenchymal transition and metastasis by targeting PI3K/AKT/Snail signaling of lung cancer cells. Oncol. Lett. 2018, 15, 7369-7375. [CrossRef] [PubMed]

103. Han, J.; Zhang, M.; Nie, C.; Jia, J.; Wang, F.; Yu, J.; Bi, W.; Liu, B.; Sheng, R.; He, G.; et al. miR-215 suppresses papillary thyroid cancer proliferation, migration, and invasion through the AKT/GSK-3 $\beta /$ Snail signaling by targeting ARFGEF1. Cell Death Dis. 2019, 10, 195. [CrossRef] [PubMed]

104. Chen, F.; Yang, D.; Ru, Y.; Cao, S.; Gao, A. MicroRNA-101 targets CXCL12-mediated Akt and Snail signaling pathways to inhibit cellular proliferation and invasion in papillary thyroid carcinoma. Oncol. Res. Featur. Preclin. Clin. Cancer Ther. 2019, 27, 691-701. [CrossRef]

105. He, Z.-J.; Li, W.; Chen, H.; Wen, J.; Gao, Y.-F.; Liu, Y.-J. miR-1306-3p targets FBXL5 to promote metastasis of hepatocellular carcinoma through suppressing snail degradation. Biochem. Biophys. Res. Commun. 2018, 504, 820-826. [CrossRef]

106. Yoo, J.-O.; Kwak, S.-Y.; An, H.-J.; Bae, I.-H.; Park, M.-J.; Han, Y.-H. miR-181b-3p promotes epithelial-mesenchymal transition in breast cancer cells through Snail stabilization by directly targeting YWHAG. Biochim. Biophys. Acta Mol. Cell Res. 2016, 1863, 1601-1611. [CrossRef]

107. Kwak, S.-Y.; Yoo, J.-O.; An, H.-J.; Bae, I.-H.; Park, M.-J.; Kim, J.; Han, Y.-H. miR-5003-3p promotes epithelial-mesenchymal transition in breast cancer cells through Snail stabilization and direct targeting of E-cadherin. J. Mol. Cell Biol. 2016, 8, 372-383. [CrossRef]

108. Liu, S.; Kumar, S.M.; Lu, H.; Liu, A.; Yang, R.; Pushparajan, A.; Guo, W.; Xu, X. MicroRNA-9 up-regulates E-cadherin through inhibition of NF-kB1-Snail1 pathway in melanoma. J. Pathol. 2012, 226, 61-72. [CrossRef]

109. Li, N.; Yang, L.; Sun, Y.; Wu, X. MicroRNA-16 inhibits migration and invasion via regulation of the Wnt/ $\beta$-catenin signaling pathway in ovarian cancer. Oncol. Lett. 2019, 17, 2631-2638. [CrossRef]

110. Che, G.; Gao, H.; Tian, J.; Hu, Q.; Xie, H.; Zhang, Y. MicroRNA-483-3p Promotes Proliferation, Migration, and Invasion and Induces Chemoresistance of Wilms' Tumor Cells. Pediatr. Dev. Pathol. 2019. [CrossRef]

111. Zhang, Z.; Zhang, M.; Chen, Q.; Zhang, Q. Downregulation of microRNA-145 promotes epithelial-mesenchymal transition via regulating Snail in osteosarcoma. Cancer Gene Ther. 2017, 24, 83-88. [CrossRef] [PubMed]

112. Zhang, L.; Pang, Y.; Cui, X.; Jia, W.; Cui, W.; Liu, Y.; Liu, C.; Li, F. MicroRNA-410-3p upregulation suppresses proliferation, invasion and migration, and promotes apoptosis in rhabdomyosarcoma cells. Oncol. Lett. 2019, 18, 936-943. [CrossRef] [PubMed] 
113. Tang, T.; Yang, Z.; Zhu, Q.; Wu, Y.; Sun, K.; Alahdal, M.; Zhang, Y.; Xing, Y.; Shen, Y.; Xia, T.; et al. Up-regulation of miR-210 induced by a hypoxic microenvironment promotes breast cancer stem cell metastasis, proliferation, and self-renewal by targeting E-cadherin. FASEB J. 2018, 32, 6965-6981. [CrossRef] [PubMed]

114. Hwang, W.-L.; Jiang, J.-K.; Yang, S.-H.; Huang, T.-S.; Lan, H.-Y.; Teng, H.-W.; Yang, C.-Y.; Tsai, Y.-P.; Lin, C.-H.; Wang, H.-W.; et al. MicroRNA-146a directs the symmetric division of Snail-dominant colorectal cancer stem cells. Nat. Cell Biol. 2014, 16, 268-280. [CrossRef]

115. Qu, Y.; Li, W.-C.; Hellem, M.R.; Rostad, K.; Popa, M.; McCormack, E.; Oyan, A.M.; Kalland, K.-H.; Ke, X.-S. MiR-182 and miR-203 induce mesenchymal to epithelial transition and self-sufficiency of growth signals via repressing SNAI2 in prostate cells. Int. J. Cancer 2013, 133, 544-555. [CrossRef]

116. Yu, C.-C.; Chen, P.-N.; Peng, C.-Y.; Yu, C.-H.; Chou, M.-Y. Suppression of miR-204 enables oral squamous cell carcinomas to promote cancer stemness, EMT traits, and lymph node metastasis. Oncotarget 2016, 7, 20180. [CrossRef]

117. Liao, H.; Bai, Y.; Qiu, S.; Zheng, L.; Huang, L.; Liu, T.; Wang, X.; Liu, Y.; Xu, N.; Yan, X.; et al. MiR-203 downregulation is responsible for chemoresistance in human glioblastoma by promoting epithelial-mesenchymal transition via SNAI2. Oncotarget 2015, 6, 8914-8928. [CrossRef]

118. Tominaga, E.; Yuasa, K.; Shimazaki, S.; Hijikata, T. MicroRNA-1 targets Slug and endows lung cancer A549 cells with epithelial and anti-tumorigenic properties. Exp. Cell Res. 2013, 319, 77-88. [CrossRef]

119. Liang, Y.-J.; Wang, Q.-Y.; Zhou, C.-X.; Yin, Q.-Q.; He, M.; Yu, X.-T.; Cao, D.-X.; Chen, G.-Q.; He, J.-R.; Zhao, Q. MiR-124 targets Slug to regulate epithelial-mesenchymal transition and metastasis of breast cancer. Carcinogenesis 2013, 34, 713-722. [CrossRef]

120. Du, S.; Li, H.; Sun, X.; Li, D.; Yang, Y.; Tao, Z.; Li, Q.; Liu, K. MicroRNA-124 inhibits cell proliferation and migration by regulating SNAI2 in breast cancer. Oncol. Rep. 2016, 36, 3259-3266. [CrossRef]

121. Wu, Z.; Li, X.; Cai, X.; Huang, C.; Zheng, M. miR-497 inhibits epithelial mesenchymal transition in breast carcinoma by targeting Slug. Tumor Biol. 2016, 37, 7939-7950. [CrossRef] [PubMed]

122. Liu, B.-W.; Yu, Z.-H.; Chen, A.-X.; Chi, J.-R.; Ge, J.; Yu, Y.; Cao, X.-C. Estrogen receptor- $\alpha$-miR-1271-SNAI2 feedback loop regulates transforming growth factor- $\beta$-induced breast cancer progression. J. Exp. Clin. Cancer Res. 2019, 38, 109. [CrossRef] [PubMed]

123. Zhang, Z.; Zhang, B.; Li, W.; Fu, L.; Fu, L.; Zhu, Z.; Dong, J.-T. Epigenetic Silencing of miR-203 Upregulates SNAI2 and Contributes to the Invasiveness of Malignant Breast Cancer Cells. Genes Cancer 2011, 2, 782-791. [CrossRef] [PubMed]

124. Ding, X.; Park, S.I.; McCauley, L.K.; Wang, C.-Y. Signaling between Transforming Growth Factor $\beta$ (TGF- $\beta$ ) and Transcription Factor SNAI2 Represses Expression of MicroRNA miR-203 to Promote Epithelial-Mesenchymal Transition and Tumor Metastasis. J. Biol. Chem. 2013, 288, 10241-10253. [CrossRef] [PubMed]

125. Chen, D.-D.; Cheng, J.-T.; Chandoo, A.; Sun, X.-W.; Zhang, L.; Lu, M.-D.; Sun, W.-J.; Huang, Y.-P. microRNA-33a prevents epithelial-mesenchymal transition, invasion, and metastasis of gastric cancer cells through the Snail/Slug pathway. Am. J. Physiol. Liver Physiol. 2019, 317, G147-G160. [CrossRef] [PubMed]

126. Shi, Z.-M.; Wang, L.; Shen, H.; Jiang, C.-F.; Ge, X.; Li, D.-M.; Wen, Y.-Y.; Sun, H.-R.; Pan, M.-H.; Li, W.; et al. Downregulation of miR-218 contributes to epithelial-mesenchymal transition and tumor metastasis in lung cancer by targeting Slug/ZEB2 signaling. Oncogene 2017, 36, 2577-2588. [CrossRef] [PubMed]

127. Xiao, H.; Zeng, J.; Li, H.; Chen, K.; Yu, G.; Hu, J.; Tang, K.; Zhou, H.; Huang, Q.; Li, A.; et al. MiR-1 downregulation correlates with poor survival in clear cell renal cell carcinoma where it interferes with cell cycle regulation and metastasis. Oncotarget 2015, 6, 13201-13215. [CrossRef]

128. Huang, J.; Liang, Y.; Xu, M.; Xiong, J.; Wang, D.; Ding, Q. MicroRNA-124 acts as a tumor-suppressive miRNA by inhibiting the expression of Snail2 in osteosarcoma. Oncol. Lett. 2018, 15, 4979-4987. [CrossRef]

129. Lin, T.; Yu, C.-C.; Hsieh, P.-L.; Liao, Y.-W.; Yu, C.-H.; Chen, C.-J. Down-regulation of miR-200b-targeting Slug axis by cyclosporine A in human gingival fibroblasts. J. Formos. Med. Assoc. 2018, 117, 1072-1077. [CrossRef]

130. Xia, H.; Cheung, W.K.C.; Ng, S.S.; Jiang, X.; Jiang, S.; Sze, J.; Leung, G.K.K.; Lu, G.; Chan, D.T.M.; Bian, X.-W.; et al. Loss of Brain-enriched miR-124 MicroRNA Enhances Stem-like Traits and Invasiveness of Glioma Cells. J. Biol. Chem. 2012, 287, 9962-9971. [CrossRef]

131. Sun, Y.; Cai, J.; Yu, S.; Chen, S.; Li, F.; Fan, C. MiR-630 Inhibits Endothelial-Mesenchymal Transition by Targeting Slug in Traumatic Heterotopic Ossification. Sci. Rep. 2016, 6, 22729. [CrossRef] [PubMed] 
132. Dai, X.; Liang, Z.; Liu, L.; Guo, K.; Xu, S.; Wang, H. Silencing of MALAT1 inhibits migration and invasion by sponging miR-1-3p in prostate cancer cells. Mol. Med. Rep. 2019, 20, 3499-3508. [CrossRef] [PubMed]

133. Jin, C.; Yan, B.; Lu, Q.; Lin, Y.; Ma, L. The role of MALAT1/miR-1/slug axis on radioresistance in nasopharyngeal carcinoma. Tumor Biol. 2016, 37, 4025-4033. [CrossRef] [PubMed]

134. Gan, L.; Lv, L.; Liao, S. Long non-coding RNA H19 regulates cell growth and metastasis via the miR-22-3p/Snail1 axis in gastric cancer. Int. J. Oncol. 2019, 54, 2157-2168. [CrossRef]

135. Zhang, Y.; Yuan, Y.; Zhang, Y.; Cheng, L.; Zhou, X.; Chen, K. SNHG7 accelerates cell migration and invasion through regulating miR-34a-Snail-EMT axis in gastric cancer. Cell Cycle 2020, 19, 142-152. [CrossRef]

136. Yang, P.; Chen, T.; Xu, Z.; Zhu, H.; Wang, J.; He, Z. Long noncoding RNA GAPLINC promotes invasion in colorectal cancer by targeting SNAI2 through binding with PSF and NONO. Oncotarget 2016, 7, 42183-42194. [CrossRef]

137. Ge, X.; Li, G.; Jiang, L.; Jia, L.; Zhang, Z.; Li, X.; Wang, R.; Zhou, M.; Zhou, Y.; Zeng, Z.; et al. Long noncoding RNA CAR10 promotes lung adenocarcinoma metastasis via miR-203/30/SNAI axis. Oncogene 2019, 38, 3061-3076. [CrossRef]

138. Jiang, L.; Wang, R.; Fang, L.; Ge, X.; Chen, L.; Zhou, M.; Zhou, Y.; Xiong, W.; Hu, Y.; Tang, X.; et al. HCP5 is a SMAD3-responsive long non-coding RNA that promotes lung adenocarcinoma metastasis via miR-203/SNAI axis. Theranostics 2019, 9, 2460-2474. [CrossRef]

139. Xiao, J.-N.; Yan, T.-H.; Yu, R.-M.; Gao, Y.; Zeng, W.-L.; Lu, S.-W.; Que, H.-X.; Liu, Z.-P.; Jiang, J.-H. Long non-coding RNA UCA1 regulates the expression of Snail2 by miR-203 to promote hepatocellular carcinoma progression. J. Cancer Res. Clin. Oncol. 2017, 143, 981-990. [CrossRef]

140. Xiao, C.; Wan, X.; Yu, H.; Chen, X.; Shan, X.; Miao, Y.; Fan, R.; Cha, W. LncRNA-AB209371 promotes the epithelial-mesenchymal transition of hepatocellular carcinoma cells. Oncol. Rep. 2019, 41, 2957-2966. [CrossRef]

141. Wang, Y.Q.; Jiang, D.M.; Hu, S.S.; Zhao, L.; Wang, L.; Yang, M.H.; Ai, M.L.; Jiang, H.J.; Han, Y.; Ding, Y.Q.; et al. SATB2-AS1 suppresses colorectal carcinoma aggressiveness by inhibiting SATB2-dependent Snail transcription and epithelial-mesenchymal transition. Cancer Res. 2019, 79, 3542-3556. [CrossRef] [PubMed]

142. Li, Y.; Cheng, C. Long noncoding RNA NEAT1 promotes the metastasis of osteosarcoma via interaction with the G9a-DNMT1-Snail complex. Am. J. Cancer Res. 2018, 8, 81-90. [PubMed]

143. Jiang, H.; Li, T.; Qu, Y.; Wang, X.; Li, B.; Song, J.; Sun, X.; Tang, Y.; Wan, J.; Yu, Y.; et al. Long non-coding RNA SNHG15 interacts with and stabilizes transcription factor Slug and promotes colon cancer progression. Cancer Lett. 2018, 425, 78-87. [CrossRef] [PubMed]

144. Luan, W.; Shi, Y.; Zhou, Z.; Xia, Y.; Wang, J. circRNA_0084043 promote malignant melanoma progression via miR-153-3p/Snail axis. Biochem. Biophys. Res. Commun. 2018, 502, 22-29. [CrossRef] [PubMed]

145. Chen, X.; Chen, R.X.; Wei, W.S.; Li, Y.H.; Feng, Z.H.; Tan, L.; Chen, J.W.; Yuan, G.J.; Chen, S.L.; Guo, S.J.; et al. PRMT5 circular RNA promotes metastasis of urothelial carcinoma of the bladder through sponging miR-30c to induce epithelial-mesenchymal transition. Clin. Cancer Res. 2018, 24, 6319-6330. [CrossRef] [PubMed]

146. Ma, H.-B.; Yao, Y.-N.; Yu, J.-J.; Chen, X.-X.; Li, H.-F. Extensive profiling of circular RNAs and the potential regulatory role of circRNA-000284 in cell proliferation and invasion of cervical cancer via sponging miR-506. Am. J. Transl. Res. 2018, 10, 592-604. [PubMed]

147. Wang, L.; Tong, X.; Zhou, Z.; Wang, S.; Lei, Z.; Zhang, T.; Liu, Z.; Zeng, Y.; Li, C.; Zhao, J.; et al. Circular RNA hsa-circ-0008305 (circPTK2) inhibits TGF- $\beta$-induced epithelial-mesenchymal transition and metastasis by controlling TIF1 $\gamma$ in non-small cell lung cancer. Mol. Cancer 2018, 17, 140. [CrossRef]

148. Chi, Y.; Luo, Q.; Song, Y.; Yang, F.; Wang, Y.; Jin, M.; Zhang, D. Circular RNA circPIP5K1A promotes non-small cell lung cancer proliferation and metastasis through miR-600/HIF-1 $\alpha$ regulation. J. Cell. Biochem. 2019, 120, 19019-19030. [CrossRef]

149. Shen, T.; Cheng, X.; Liu, X.; Xia, C.; Zhang, H.; Pan, D.; Zhang, X.; Li, Y. Circ_0026344 restrains metastasis of human colorectal cancer cells via miR-183. Artif. Cells Nanomed. Biotechnol. 2019, 47, 4038-4045. [CrossRef]

150. Kumar, A.S.; Jagadeeshan, S.; Pitani, R.S.; Ramshankar, V.; Venkitasamy, K.; Venkatraman, G.; Rayala, S.K. Snail-Modulated MicroRNA 493 Forms a Negative Feedback Loop with the Insulin-Like Growth Factor 1 Receptor Pathway and Blocks Tumorigenesis. Mol. Cell. Biol. 2017, 37, e00510-16. [CrossRef] 
151. Zhu, Y.; Wang, C.; Becker, S.A.; Hurst, K.; Nogueira, L.M.; Findlay, V.J.; Camp, E.R. miR-145 Antagonizes SNAI1-Mediated Stemness and Radiation Resistance in Colorectal Cancer. Mol. Ther. 2018, 26, 744-754. [CrossRef] [PubMed]

152. Xu, Y.; Jin, J.; Liu, Y.; Huang, Z.; Deng, Y.; You, T.; Zhou, T.; Si, J.; Zhuo, W. Snail-Regulated MiR-375 Inhibits Migration and Invasion of Gastric Cancer Cells by Targeting JAK2. PLoS ONE 2014, 9, e99516. [CrossRef] [PubMed]

153. Hsieh, C.-H.; Tai, S.-K.; Yang, M.-H. Snail-overexpressing Cancer Cells Promote M2-Like Polarization of Tumor-Associated Macrophages by Delivering MiR-21-Abundant Exosomes. Neoplasia 2018, 20, 775-788. [CrossRef] [PubMed]

154. Dong, Q.; Cai, N.; Tao, T.; Zhang, R.; Yan, W.; Li, R.; Zhang, J.; Luo, H.; Shi, Y.; Luan, W.; et al. An Axis Involving SNAI1, microRNA-128 and SP1 Modulates Glioma Progression. PLoS ONE 2014, 9, e98651. [CrossRef]

155. Qian, P.; Banerjee, A.; Wu, Z.-S.; Zhang, X.; Wang, H.; Pandey, V.; Zhang, W.-J.; Lv, X.-F.; Tan, S.; Lobie, P.E.; et al. Loss of SNAIL Regulated miR-128-2 on Chromosome 3p22.3 Targets Multiple Stem Cell Factors to Promote Transformation of Mammary Epithelial Cells. Cancer Res. 2012, 72, 6036-6050. [CrossRef]

156. Yu, W.-W.; Jiang, H.; Zhang, C.-T.; Peng, Y. The SNAIL/miR-128 axis regulated growth, invasion, metastasis, and epithelial-to-mesenchymal transition of gastric cancer. Oncotarget 2017, 8, 39280-39295. [CrossRef]

157. Tao, T.; Li, G.; Dong, Q.; Liu, D.; Liu, C.; Han, D.; Huang, Y.; Chen, S.; Xu, B.; Chen, M. Loss of SNAIL inhibits cellular growth and metabolism through the miR-128-mediated RPS6KB1/HIF-1 $\alpha /$ PKM2 signaling pathway in prostate cancer cells. Tumor Biol. 2014, 35, 8543-8550. [CrossRef]

158. Díaz-López, A.; Díaz-Martín, J.; Moreno-Bueno, G.; Cuevas, E.P.; Santos, V.; Olmeda, D.; Portillo, F.; Palacios, J.; Cano, A. Zeb1 and Snaill engage miR-200f transcriptional and epigenetic regulation during EMT. Int. J. Cancer 2015, 136, E62-E73. [CrossRef]

159. Gill, J.G.; Langer, E.M.; Lindsley, R.C.; Cai, M.; Murphy, T.L.; Murphy, K.M. Snail promotes the cell-autonomous generation of Flk1(+) endothelial cells through the repression of the microRNA-200 family. Stem Cells Dev. 2012, 21, 167-176. [CrossRef]

160. Liu, Z.; Liu, H.; Desai, S.; Schmitt, D.C.; Zhou, M.; Khong, H.T.; Klos, K.S.; McClellan, S.; Fodstad, O.; Tan, M. miR-125b Functions as a Key Mediator for Snail-induced Stem Cell Propagation and Chemoresistance. J. Biol. Chem. 2013, 288, 4334-4345. [CrossRef]

161. Lerner, R.G.; Petritsch, C. A microRNA-operated switch of asymmetric-to-symmetric cancer stem cell divisions. Nat. Cell Biol. 2014, 16, 212-214. [CrossRef] [PubMed]

162. Yi, M.; Liu, B.; Tang, Y.; Li, F.; Qin, W.; Yuan, X. Irradiated Human Umbilical Vein Endothelial Cells Undergo Endothelial-Mesenchymal Transition via the Snail/miR-199a-5p Axis to Promote the Differentiation of Fibroblasts into Myofibroblasts. BioMed Res. Int. 2018, 2018, 1-10. [CrossRef] [PubMed]

163. He, J.-H.; Li, B.-X.; Han, Z.-P.; Zou, M.-X.; Wang, L.; Lv, Y.-B.; Zhou, J.-B.; Cao, M.-R.; Li, Y.-G.; Zhang, J. Snail-activated long non-coding RNA PCA3 up-regulates PRKD3 expression by miR-1261 sponging, thereby promotes invasion and migration of prostate cancer cells. Tumor Biol. 2016, 37, 16163-16176. [CrossRef] [PubMed]

164. Mazzolini, R.; Gonzàlez, N.; Garcia-Garijo, A.; Millanes-Romero, A.; Peiró, S.; Smith, S.; De Herreros, A.G.; Canudas, S. Snail1 transcription factor controls telomere transcription and integrity. Nucleic Acids Res. 2018, 46, 146-158. [CrossRef] [PubMed]

165. Battistelli, C.; Cicchini, C.; Santangelo, L.; Tramontano, A.; Grassi, L.; Gonzalez, F.J.; De Nonno, V.; Grassi, G.; Amicone, L.; Tripodi, M. The Snail repressor recruits EZH2 to specific genomic sites through the enrollment of the lncRNA HOTAIR in epithelial-to-mesenchymal transition. Oncogene 2017, 36, 942-955. [CrossRef]

166. Findlay, V.J.; Wang, C.; Nogueira, L.M.; Hurst, K.; Quirk, D.; Ethier, S.P.; Staveley O'Carroll, K.F.; Watson, D.K.; Camp, E.R. SNAI2 Modulates Colorectal Cancer 5-Fluorouracil Sensitivity through miR145 Repression. Mol. Cancer Ther. 2014, 13, 2713-2726. [CrossRef]

167. Chang, T.-H.; Tsai, M.-F.; Gow, C.-H.; Wu, S.-G.; Liu, Y.-N.; Chang, Y.-L.; Yu, S.-L.; Tsai, H.-C.; Lin, S.-W.; Chen, Y.-W.; et al. Upregulation of microRNA-137 expression by Slug promotes tumor invasion and metastasis of non-small cell lung cancer cells through suppression of TFAP2C. Cancer Lett. 2017, 402, 190-202. [CrossRef] 
168. Liu, Y.-N.; Yin, J.J.; Abou-Kheir, W.; Hynes, P.G.; Casey, O.M.; Fang, L.; Yi, M.; Stephens, R.M.; Seng, V.; Sheppard-Tillman, H.; et al. MiR-1 and miR-200 inhibit EMT via Slug-dependent and tumorigenesis via Slug-independent mechanisms. Oncogene 2013, 32, 296-306. [CrossRef]

169. Pan, Y.; Li, J.; Zhang, Y.; Wang, N.; Liang, H.; Liu, Y.; Zhang, C.-Y.; Zen, K.; Gu, H. Slug-upregulated miR-221 promotes breast cancer progression through suppressing E-cadherin expression. Sci. Rep. 2016, 6, 25798. [CrossRef]

170. Zheng, M.; Jiang, Y.; Chen, W.; Li, K.; Liu, X.; Gao, S.; Feng, H.; Wang, S.; Jiang, J.; Ma, X.; et al. Snail and Slug collaborate on EMT and tumor metastasis through miR-101-mediated EZH2 axis in oral tongue squamous cell carcinoma. Oncotarget 2015, 6, 6797-6810. [CrossRef]

171. Xiong, W.-C.; Han, N.; Wu, N.; Zhao, K.-L.; Han, C.; Wang, H.-X.; Ping, G.-F.; Zheng, P.-F.; Feng, H.; Qin, L.; et al. Interplay between long noncoding RNA ZEB1-AS1 and miR-101/ZEB1 axis regulates proliferation and migration of colorectal cancer cells. Am. J. Transl. Res. 2018, 10, 605-617. [PubMed]

172. Hahn, S.; Jackstadt, R.; Siemens, H.; Hünten, S.; Hermeking, H. SNAIL and miR-34a feed-forward regulation of ZNF281/ZBP99 promotes epithelial-mesenchymal transition. EMBO J. 2013, 32, 3079-3095. [CrossRef] [PubMed]

173. Hahn, S.; Hermeking, H. ZNF281/ZBP-99: A new player in epithelial-mesenchymal transition, stemness, and cancer. J. Mol. Med. 2014, 92, 571-581. [CrossRef] [PubMed]

174. Fumagalli, M.R.; Lionetti, M.C.; Zapperi, S.; La Porta, C.A.M. Cross-Talk Between circRNAs and mRNAs Modulates MiRNA-mediated Circuits and Affects Melanoma Plasticity. Cancer Microenviron. 2019, 12, 95-104. [CrossRef] [PubMed]

175. Liu, Y.; Xue, M.; Du, S.; Feng, W.; Zhang, K.; Zhang, L.; Liu, H.; Jia, G.; Wu, L.; Hu, X.; et al. Competitive endogenous RNA is an intrinsic component of EMT regulatory circuits and modulates EMT. Nat. Commun. 2019, 10, 1637. [CrossRef] [PubMed]

176. Zhang, L.; Liao, Y.; Tang, L. MicroRNA-34 family: A potential tumor suppressor and therapeutic candidate in cancer. J. Exp. Clin. Cancer Res. 2019, 38, 53. [CrossRef]

(C) 2020 by the authors. Licensee MDPI, Basel, Switzerland. This article is an open access article distributed under the terms and conditions of the Creative Commons Attribution (CC BY) license (http://creativecommons.org/licenses/by/4.0/). 